\title{
Articulo Original / Original Article \\ Phytochemical composition, antifungal activity, in vitro and in vivo toxicity of Syzygium cumini (L.) Skeels leaves extract
}

\author{
[Composición fitoquímica, actividad antifúngica, toxicidad in vitro e in vivo del extracto \\ de hojas de Sysygium cumini (L.) Skeels]
}

\begin{abstract}
Ernani Canuto Figueirêdo Júnior ${ }^{1}$, Yuri Wanderley Cavalcanti ${ }^{2}$, Andressa Brito Lira ${ }^{3}$, Hilzeth de Luna Freire Pessôa ${ }^{3}$, Wilton Silva Lopes ${ }^{4}$, Diego Romário da Silva ${ }^{5}$, Irlan Almeida Freires ${ }^{5}$, Pedro Luiz Rosalen ${ }^{5}$, Edja Maria Melo de Brito $\operatorname{Costa}^{1} \&$ Jozinete Vieira Pereira ${ }^{1}$

\author{
${ }^{1}$ Graduate Program in Dentistry, State University of Paraíba, Campina Grande, Brazil \\ ${ }^{2}$ Department of Clinics and Social Dentistry, Federal University of Paraíba, João Pessoa, Brazil \\ ${ }^{3}$ Graduate Program in Natural and Synthetic Bioactive Products, Federal University of Paraíba, João Pessoa, Brazil \\ ${ }^{4}$ Graduate Program in Environmental Science and Technology, State University of Paraíba, Campina Grande, Brazil \\ ${ }^{5}$ Department of Physiological Sciences (Pharmacology, Anesthesiology and Therapeutics), Piracicaba Dental School, University of \\ Campinas, Piracicaba, Brazil
}

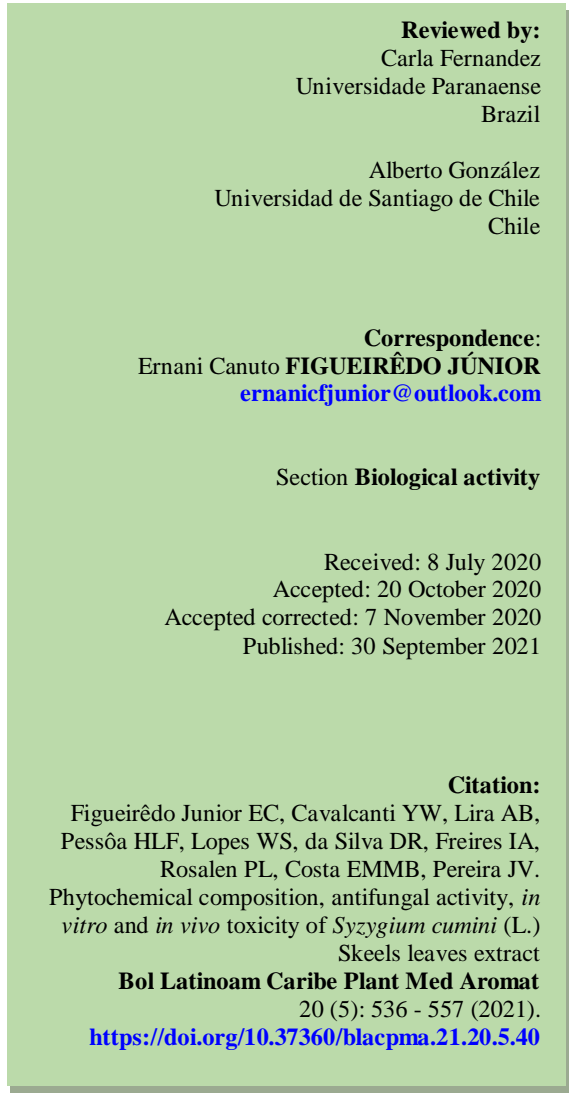

Abstract: This study determined phytochemical composition, antifungal activity and toxicity in vitro and in vivo of Syzygium cumini leaves extract (Sc). Thus, was characterized by gas chromatography coupled to mass spectrometry and submitted to determination of Minimum Inhibitory (MIC) and Fungicidal concentrations (MFC) on reference and clinical strains of Candida spp. and by growth kinetics assays. Toxicity was verified using in vitro assays of hemolysis, osmotic fragility, oxidant and antioxidant activity in human erythrocytes and by in vivo acute systemic toxicity in Galleria mellonella larvae. Fourteen different compounds were identified in Sc, which showed antifungal activity (MIC between 31.25-125 $\mu \mathrm{g} / \mathrm{mL}$ ) with fungistatic effect on Candida. At antifungal concentrations, it demonstrated low cytotoxicity, antioxidant activity and neglible in vivo toxicity. Thus, Sc demonstrated a promising antifungal potential, with low toxicity, indicating that this extract can be a safe and effective alternative antifungal agent.

Keywords: Dentistry; Plants extracts; Syzygium cumini; Antifungal agents; Toxicity tests.

Resumen: Este estudio determinó la composición fitoquímica, la actividad antifúngica y la toxicidad in vitro e in vivo del extracto de hojas de Syzygium cumini (Sc). Así, se caracterizó mediante cromatografía de gases acoplada a espectrometría de masas y se sometió a determinación de Concentraciones Mínimas Inhibitorias (CMI) y Fungicidas (MFC) sobre cepas de referencia y clínicas de Candida spp. y mediante ensayos de cinética de crecimiento. La toxicidad se verificó mediante ensayos in vitro de hemólisis, fragilidad osmótica, actividad oxidante y antioxidante en eritrocitos humanos y por toxicidad sistémica aguda in vivo en larvas de Galleria mellonella. Se identificaron catorce compuestos diferentes en Sc, que mostraron actividad antifúngica (CMI entre 31.25-125 $\mu \mathrm{g} / \mathrm{mL}$ ) con efecto fungistático sobre Candida. En concentraciones antifúngicas, demostró baja citotoxicidad, actividad antioxidante y toxicidad in vivo insignificante. Por lo tanto, Sc demostró un potencial antifúngico prometedor, con baja toxicidad, lo que indica que este extracto puede ser un agente antifúngico alternativo seguro y eficaz.

Palabras clave: Odontología; Extractos de plantas; Syzygium cumini; Agentes antifúngicos; Ensayos de toxicidad. 


\section{INTRODUCTION}

Medicinal plants have been long considered promising resources for the discovery of new therapeutic agents to treat human diseases (Pereira $e t$ al., 2016; De Araújo et al., 2018) such as oral candidiasis caused by Candida spp. (Peleg et al., 2010; Rodrigues et al., 2014; Muadcheingka \& Tantivitayakul, 2015; Silva-Rocha et al., 2015).

Oral candidiasis is a superficial fungal infection which may present clinically as pseudomembranous candidiasis, erythematous candidiasis, hyperplastic candidiasis, denture stomatitis or angular cheilitis. $C$. albicans is the predominant species in oral candidiasis, with rates of prevalence of $61.6 \%$ followed by non albicans species that has increased significantly such as $C$. glabrata (15.2\%), C. tropicalis (10.4\%), C. krusei (1.6\%), among others (Muadcheingka \& Tantivitayakul, 2015), with reports of high azole resistance rates in this species, specially to fluconazole, with resistance rates from 9 to $14 \%$ in $C$. glabrata and $11.6 \%$ in C. tropicalis (Perlin et al., 2017).

Fungal infections range from superficial mucosal (of importance in Dentistry), dermal infections, and hematogenously disseminated infections with sizable mortality rates, next to $50 \%$ (Gulati \& Nobile, 2016) to $72.2 \%$ (Doi et al., 2016), especialy in immunocompromised individuals or in critically ill patients (Doi et al., 2016; Gulati \& Nobile, 2016; Savastano et al., 2016). Thus, oral candidiasis and disseminated infections caused by Candida remains a public health issue, with high prevalence rates worldwide (Doi et al., 2016; Pereira et al., 2016; Savastano et al., 2016). The study of naturally-occurring molecules has gained relevance particularly because of the increasingly rates of microbial resistance and substantial toxicity caused by administration of current antifungal drugs (Coleman et al., 2010; Doi et al., 2016; Gulati \& Nobile, 2016; Pereira et al., 2016; Savastano et al., 2016), such as fluconazole, itraconazole, miconazole and amphotericin B (Doi et al., 2016; Gulati \& Nobile, 2016; Savastano et al., 2016), which can cause adverse effects such as nausea and vomiting, headach, hepatotoxicity, gastrointestinal disturbance, skin irritation, burning sensation, deppending of class or type of antifungal agent (Millsop \& Fazel, 2016).

Therefore, there is a need to investigate the effectiveness of natural products such as plant extracts as potential complementary therapeutic agents for dental use (De Araújo et al., 2018). Syzygium cumini (L.) Skeels (synonyms: Syzygium jambolanum, Syzygium jambolana, Eugenia cumini, Eugenia jambolana, Eugenia Caryophyllifolia), Myrtaceae, popularly known as jambolan, olive or purple olive, among other names, can be found in subtropical regions, including Brazil (Migliato et al., 2006; Migliato et al., 2007; Ayyanar \& Subash-Babu, 2012; Baliga et al., 2013; Srivastava \& Chandra, 2013; Chagas et al., 2015). This plant has been used in folk medicine for the treatment of various diseases especially diabetes for its hypoglycemic effects (Migliato et al., 2006; Migliato et al., 2007; Ayyanar \& Subash-Babu, 2012; Baliga et al., 2013; Chagas et al., 2015). However, there are also reports of pharmacological studies that includes biological activities such as anti-inflammatory, cardioprotective, antioxidant, antimicrobial/antibacterial and antifungal effects (Migliato et al., 2007; Ayyanar \& SubashBabu, 2012; Baliga et al., 2013; Chagas et al., 2015). Especially, some studies highlight its antifungal activity against Candida spp. (Oliveira et al., 2007; Höfling et al., 2010; Pereira et al., 2016), such as $C$. albicans (Oliveira et al., 2007; Höfling et al., 2010; Pereira et al., 2016), C. krusei (Oliveira et al., 2007; Höfling et al.,2010), C. dubliniensis, C. glabrata, C. guilliermondii, $C$. lusitaniae, $C$. parapsilosis, $C$. rugosa, C. tropicalis and C. utilis (Höfling et al., 2010).

The leaves are specially used in dermopathies, gastropathies, constipation, leucorrhea, diabetes (Chagas et al., 2015) and there are evidences showing its antifungal activity (Oliveira et al., 2007; Pereira et al., 2016). Besides that, reports in the literature of different compounds such as flavonoids, terpenoids and phenolics, and specifically sitosterol, betulinic acid, crategolic acid, quercetin, myricetin, methylgallate, kaempferol (Srivastava \& Chandra, 2013), acylated flavonol glycosides, quercetin, myricetin, myricitin, myricetin 3-O-4-acetyl-Lrhamnopyranoside, triterpenoids, esterase, galloyl carboxylase and tannin (Ayyanar \& Subash-Babu, 2012) have been reported to be present in the leaves of $S$. cumini.

Thus, since previous evidence showed a potential antimicrobial effect of $S$. cumini leaves extract (Sc) (Pereira et al., 2016) and has encouraged further investigation on the antifungal activity of the extract against additional yeast strains. The present 
study was designed to investigate the phytochemical composition of the extract and determine its antifungal activity against different reference strains and clinical isolates of Candida spp. Further toxicological assessment of the extract was carried out in the present study in vitro and in vivo.

Three hypotheses were tested during the evaluation of the biological properties of $S$. cumini extract, namely: (1) the extract has inhibitory activity against Candida spp.; (2) the extract is biologically compatible with human erythrocytes, and (3) the extract is not toxic in an in vivo model of Galleria mellonella larvae.

\section{MATERIAL AND METHODS}

\section{Plant material}

The plant material used in this study consisted of Syzygium cumini leaves, which were collected in August 2013 in Campina Grande, Paraíba State, Brazil ( $\left.7^{\circ} 22^{\prime} 25^{\prime \prime} \mathrm{S}, 35^{\circ} 59^{\prime} 32^{\prime \prime} \mathrm{W}\right)$, botanically identified in herbarium Lauro Pires Xavier at the Department of Molecular Biology, Federal University of Paraíba, João Pessoa, Paraíba, with voucher number JPB 58.543. The present research was registered in the National System of Genetic Heritage Management and Association Traditional Knowledge of the Brazilian Ministry of the Environment unde number A3223F1. To obtain a hydroalcoholic extract, plant material was processed through cleaning, drying in an air-circulating oven at $40^{\circ} \mathrm{C}$ until stabilization of final weight and grinding in a Wiley mill (SL 30 Solab, Piracicaba, SP, Brazil) of 10 mesh. Finally, hydroalcoholic extracts was prepared by maceration following the proportion $200 \mathrm{~g}$ of ground plant to $1000 \mathrm{~mL}$ of $70 \%$ hydroalcoholic solution (purity grade PA 99,5\%) and after that the extract was subjected to evaporation under reduced pressure and lyophilized (LS 3000 Terroni ${ }^{\circledR}$ ) at $-20^{\circ}$ to $-40^{\circ} \mathrm{C}$ (Pereira et al., 2016).

\section{Phytochemical analysis: Extraction method}

The plant material was extracted as previously described (Rigobello et al., 2015), with modifications. Briefly, Sc leaves were submitted to liquid-liquid extraction and solid-phase extraction. The extract obtained was weighed, dissolved into $40 \%$ ethanol solution (purity grade PA 99,5\%), diluted into ultrapure water and filtered. The resulting extract ( $\mathrm{pH}=7.0$ ) was placed in a separatory funnel, followed by addition of $10 \mathrm{~g}$ of $\mathrm{NaCl}$. The organic compounds were extracted by the addition of ethyl acetate (purity grade PA). The mixture was allowed to stand, then the organic phase was partitioned and then transferred to a beaker to dry, followed by addition of $20 \mathrm{~g}$ of anhydrous $\mathrm{NaSO}_{4}$ (purity grade 99\%). The supernatant was filtered, and the extracted organic phase was placed into a desiccator until reduced to a volume of $3 \mathrm{~mL}$.

\section{Cromatographic analysis}

The organic compounds present in the extract were identified by gas chromatography coupled to mass spectrometry (GC-MS) using a gas chromatograph (Thermo Scientific TRACE 1300) coupled to a mass spectrometer with quadrupole analyzer (Thermo Scientific ISQ-QD). The analysis was performed by means of chromatographic separation on an HP-5MS fused silica capillary column $(30 \mathrm{~m}$ x $0.25 \mathrm{~mm} \times 0.50$ $\mu \mathrm{m})$ (Varian Technlogies, EZ-Guard Columns) and on an SPB-624 column (30 m x $0.25 \mathrm{~mm} \times 0.50 \mu \mathrm{m})$.

The GC oven temperature setting for both columns was $40^{\circ} \mathrm{C}$ for $2 \mathrm{~min}, 5^{\circ} \mathrm{C} / \mathrm{min}$ to $70{ }^{\circ} \mathrm{C}$ maintained for $10 \mathrm{~min}$, and $10^{\circ} \mathrm{C} / \mathrm{min}$ to $200^{\circ} \mathrm{C}$ for 30 min. Helium was used as the carrier gas with a flow rate of $1 \mathrm{~mL} / \mathrm{min}$. The injector temperature used was $250^{\circ} \mathrm{C}$ in splitless mode for a ratio of 33.3.

The volume of the injected material was $1 \mu \mathrm{L}$ and the detection was performed by a selective mass detector equipped with an electron impact source at $70 \mathrm{eV}$. Data acquisition was obtained in full scan mode. The temperature of the ion source and the transfer line of the mass spectrometer were $250^{\circ} \mathrm{C}$ and $275^{\circ} \mathrm{C}$, respectively. The scanning range of $\mathrm{m} / \mathrm{z}$ was from 50 to 650 with a solvent cut-off time of 5 $\min$.

The chemical compounds were characterized by comparison between the mass spectra obtained in the GC-MS analysis and those found in the NIST library (National Institute of Standards and Technology) (The NIST Mass Spectral Search Program for the NIST/EPA/NIH Mass Spectral library version $2.0 \mathrm{~g}$. build May 19, 2011) as described (Rigobello et al., 2015), with modifications.

Microorganisms, growth conditions, and antifungal activity of Sc extract

Reference strains of Candida albicans (ATCC 10231), C. glabrata (ATCC 90030), C. krusei (ATCC 6258), C. tropicalis (ATCC 750) and clinical 
strains of C. albicans (LM1 and LM3) were used. The inocula were prepared according to the protocol M27-A3 for yeasts (CLSI, 2008), with modifications, using Sabouraud Dextrose broth (Difco, Detroit, USA) and standardized in a spectrophotometer (Model GT 7220 BioPet Technologies, Monte Alto, Brazil) at $530 \mathrm{~nm}$ (absorbance values between 0.080.1 ) and was successively diluted to a final concentration of $2.5 \times 10^{3} \mathrm{CFU} / \mathrm{mL}$ for microdilution assays.

The experiments were performed using 96well microplates (Cralpast, Cotia, Brazil). The extract was tested at concentrations ranging from 1000 to 7.8 $\mu \mathrm{g} / \mathrm{mL}$, and the standard drugs nystatin and fluconazole (Sigma-Aldrich, St. Louis, MO) were tested at concentrations from 64 to $0.5 \mu \mathrm{g} / \mathrm{mL}$. A yeast growth control, culture media sterility control and vehicle control (negative control) were also included in susceptibility assays.

The microplates were incubated at $37{ }^{\circ} \mathrm{C}$ for 24-48h. The Minimum Inhibitory Concentration (MIC) of the Sc extract and standard drugs was defined as the lowest concentration capable of inhibiting visible microbial growth (CLSI, 2008). The visual reading was further confirmed with the addition of resazurin $(0.01 \%)$ to the wells of the microplate (Sigma-Aldrich, St. Louis, MO).

The Minimal Fungicidal Concentration (MFC) was determined by subculturing $10 \mu \mathrm{L}$ of the wells corresponding to concentrations $\geq$ the MIC onto Sabouraud Dextrose Agar plates (Difco, Detroit, USA). The plates were incubated at $37{ }^{\circ} \mathrm{C}$ for $24-48$ $\mathrm{h}$, and the MFC was considered as the lowest concentration of the drug capable of inhibiting the subculture growth. The tests were carried out in triplicate of three independent experiments $(n=9)$ and the results were expressed as the mode of the replicates.

\section{Effects of Sc extract on C. albicans growth kinetics}

The effects of Sc extract on $C$. albicans (ATCC 10231) growth kinetics were determined as described (Klepser et al., 1997; Cantón et al., 2009; Dias De Castro et al., 2013), with modifications. The inocula and microdilution assays were prepared according to the step described above. After steps of microdilution, the microplates were incubated at 37 ${ }^{\circ} \mathrm{C}$ for $24 \mathrm{~h}$ and during this period, the extract, nystatin (Sigma-Aldrich, St. Louis, MO) and control groups with the dilution vehicle and only inocula (yeast viability) were kept in contact with $C$. albicans cell suspension in the microplates.

At selected time intervals $(0,1,2,3,4,6,8$, 12 and $24 \mathrm{~h}$ ), $10 \mu \mathrm{L}$ of the samples of Sc extract and nystatin at concentrations equivalent to the $1 \mathrm{xMIC}$, $2 \mathrm{xMIC}$ and $4 \mathrm{xMIC}$ and control groups were collected and plated onto Sabouraud Dextrose Agar (Difco, Detroit, USA) and incubated at $37{ }^{\circ} \mathrm{C}$ for $24-48 \mathrm{~h}$ for count of CFUs. The experiment was carried out in triplicate $(n=3)$, and the results were expressed as mean $\mathrm{CFU} / \mathrm{mL}$.

\section{Cytotoxicity analysis in human erythrocytes}

The potential deleterious effects of Sc extract on human erythrocytes were determined in vitro. Human erythrocytes types $\mathrm{A}, \mathrm{B}, \mathrm{AB}, \mathrm{O}$ were used, which were obtained from the Transfusion Unit of the Lauro Wanderley University Hospital at the Federal University of Paraíba. Samples were obtained from blood unusable for blood transfusions (blood to be discarded) (De Araújo et al., 2018; Lira et al., 2018).

The experiments followed the guidelines of the Resolution 466/2012 of the National Health Council and followed the principles outlined in the Helsinki Declaration for experimental research envolving humans. Therefore, the study was submitted and approved by the Research Ethics Committee at the State University of Paraíba, under protocol CAAE: 62508416.8.0000.5187. An informed consent of the hematological donor unit was obtained prior to material collection.

\section{Hemolytic potential of Sc extract on human erythrocytes}

Blood samples (types $\mathrm{A}, \mathrm{B}, \mathrm{AB}$ and $\mathrm{O}$ ) were collected and added to $0.9 \% \mathrm{NaCl}$ at a ratio of $1: 30$ and centrifuged (1540 g for $5 \mathrm{~min}$ ) in triplicate. The final sediment was resuspended in $0.9 \% \mathrm{NaCl}$ (purity grade PA) to obtain a suspension of $0.5 \%$ blood. After that, samples were used for the analysis of the hemolytic activity. In the group test, five hundred microliters of Sc extract at different concentrations $(31.25,62.5,125,250$ and $500 \mu \mathrm{g} / \mathrm{mL})$ were added to $2 \mathrm{~mL}$ suspensions of erythrocytes. The samples were incubated $\left(1 \mathrm{~h}\right.$ at $\left.22 \pm 2^{\circ} \mathrm{C}\right)$ under agitation $(0,25 \mathrm{~g})$. After that were centrifuged (1540 g for $5 \mathrm{~min})$ and hemolysis was quantified by spectrophotometry at a wavelength of $540 \mathrm{~nm}$ (De Araújo et al., 2018; Lira et al., 2018).

Erythrocytes suspensions ( $0 \%$ hemolysis) 
were used as a negative control and suspensions of erythrocytes plus Triton $\mathrm{X}-100$ at $1 \%$ (purity grade PA) (100\% hemolysis) were used as a positive control (De Araújo et al., 2018; Lira et al., 2018). The experiments were performed in triplicate $(n=3)$, and the results were expressed as mean \pm standard error of the mean (SEM).

\section{Analysis of osmotic fragility in human erythrocytes} Aliquots of $0.5 \mathrm{~mL}$ of the extract at different concentrations $(31.25,62.5,125,250$ and 500 $\mu \mathrm{g} / \mathrm{mL})$ were incubated $\left(1 \mathrm{~h}\right.$ at $22 \pm 2^{\circ} \mathrm{C}$ ) with $2 \mathrm{~mL}$ of erythrocytes suspensions. The samples were centrifuged (1540 g for $5 \mathrm{~min}$ ) and the supernatant was discarded. The red cells were resuspended in hypotonic sodium chloride solution $(0.24 \%)$ (purity grade PA) and agitated at $0,25 \mathrm{~g}$ during $20 \mathrm{~min}$ at 22 $\pm 2{ }^{\circ} \mathrm{C}$. Afterwards, the samples were centrifuged (1540 $\mathrm{g}$ for $5 \mathrm{~min}$ ) and hemolysis was quantified by spectrophotometry at a wavelength of $540 \mathrm{~nm}$. Suspension of erythrocytes ( $0 \%$ hemolysis) was used as a negative control, and a solution of erythrocytes plus $0.24 \%$ sodium chloride solution was used as a positive control (100\% hemolysis) (Lira et al., 2018). Three independent experiments were performed, and the results were expressed as percentage (mean \pm standard error of the mean) of hemolysis as compared to the positive control group.

\section{Oxidant and antioxidant potential of Sc extract on human erythrocytes in the presence of phenylhydrazine}

A $30 \%$ suspension of erythrocytes in PBS $(11.35 \mathrm{~g}$ $\mathrm{NaH}_{2} \mathrm{PO}_{4} .2 \mathrm{H}_{2} \mathrm{O} ; 24.36 \mathrm{~g} \mathrm{Na}_{2} \mathrm{HPO}_{4}$; and $7.18 \mathrm{~g} \mathrm{NaCl}$ for $1 \mathrm{~L} ; \mathrm{pH} 7.4$ ) (purity grade $\mathrm{PA}$ ), supplemented with glucose $(200 \mathrm{mg} / \mathrm{dL})$ at $\mathrm{pH} 7.6$ was previously prepared (De Araújo et al., 2018). To investigate the oxidant potential $0.5 \mathrm{~mL}$ of the extract at different concentrations $(31.25,62.5,125,250$ and 500 $\mu \mathrm{g} / \mathrm{mL})$ were incubated $\left(1 \mathrm{~h}\right.$ at $\left.22 \pm 2^{\circ} \mathrm{C}\right)$ under steady agitation $(0,25 \mathrm{~g})$ with $2 \mathrm{~mL}$ of this erythrocytes suspensions. Next, the samples were centrifuged (1540 $\mathrm{g}$ for $5 \mathrm{~min}$ ) and the percentage of methemoglobin (MetHb) formation in relation to total hemoglobin $(\mathrm{Hb})$ was quantified by spectrophotometry at a wavelength of $630 \mathrm{~nm}$ and $540 \mathrm{~nm}$, respectively. Phenylhidrazine (purity grade PA), an oxidizing agent was used as a positive control. Three independent experiments were performed, and the results were expressed as percentage of methemoglobin $(\mathrm{mHb})$ formation in relation to hemoglobin $(\mathrm{Hb})-\mathrm{mHb}(\% \mathrm{Hb})$ as compared to the positive control group (De Araújo et al., 2018).

To investigate the antioxidant potential, after an incubation period of $1 \mathrm{~h}$ in the step described above, $1 \mathrm{mmol} / \mathrm{L}$ of phenylhydrazine (purity grade PA) was added. The suspensions were aerated and maintained under steady agitation $(0,25 \mathrm{~g})$ for $20 \mathrm{~min}$ at $22 \pm 2{ }^{\circ} \mathrm{C}$. After this period, the samples were centrifuged (1540 g for $5 \mathrm{~min}$ ), diluted in phosphate buffer solution $\left(9 \mathrm{~g} \mathrm{Na} 2 \mathrm{HPO}_{4} .12 \mathrm{H}_{2} \mathrm{O}, 5.7 \mathrm{~g} \mathrm{KH}_{2} \mathrm{PO}_{4}\right.$ to $1 \mathrm{~L}$ ) (purity grade $\mathrm{PA}$ ), and the percentage of metHb in relation to $\mathrm{Hb}$ was quantified by spectrophotometry at $630 \mathrm{~nm}$ and $540 \mathrm{~nm}$ respectively. The percentage of metHb formed was compared with the values obtained for vitamin $\mathrm{C}$ (20 $\mathrm{mmol} / \mathrm{L}$ ) (purity grade PA), an antioxidant agent. The results expressed as the methemoglobin formation percentage, in function of hemoglobin-MetHb (\% $\mathrm{Hb})$. All experiments were performed in triplicate (De Araújo et al., 2018).

\section{Antioxidant potential of Sc extract on human erythrocytes in the presence of reactive oxygen species}

This assay was performed according to the experiments described (Lira et al., 2018), with modifications. $0.5 \mathrm{~mL}$ of the extract at concentrations of $31.25,62.5$ and $125 \mu \mathrm{g} / \mathrm{mL}$ was incubated with $2 \mathrm{ml}$ of a $0.5 \%$ erythrocytes suspension in $0.9 \% \mathrm{NaCl}$ (purity grade PA) and in the presence of a $40 \mathrm{mM}$ hydrogen peroxide solution (purity grade PA). Samples were incubated $\left(4 \mathrm{~h}\right.$ at $\left.25 \pm 2{ }^{\circ} \mathrm{C}\right)$ and after that, were centrifuged (1540 $\mathrm{g}$ for $5 \mathrm{~min})$ and hemolysis was quantified by spectrophotometry at a wavelength of $540 \mathrm{~nm}$ (Lira et al., 2018).

An erythrocyte suspension ( $0 \%$ hemolysis) was used as a negative control, and a solution of erythrocytes plus $\mathrm{H}_{2} \mathrm{O}_{2}(40 \mathrm{mM})$ was used as a positive control (100\% hemolysis). A group containing an erythrocyte suspension plus $\mathrm{H}_{2} \mathrm{O}_{2}$ and Vitamin C (1000 $\mu \mathrm{g} / \mathrm{mL})$ (purity grade PA) was also tested as the reference antioxidant (Lira et al., 2018).

The experiments were performed in triplicate, and the results were expressed as percentage (mean \pm standard error of the mean) of hemolysis as compared to the positive control group. 
In vivo acute toxicity in Galleria mellonella systemic model

The acute systemic toxicity of Sc extract was determined as previously described (Megaw et al., 2015; Rochelle et al., 2016; Sardi et al., 2017), with modifications. Increasing doses of the extract with values above those with antimicrobial activity were tested to determine its $\mathrm{LD}_{50}$ (minimum dose able to kill $50 \%$ of the larvae over time). Ten larvae weighing between 0.2 and $0.3 \mathrm{~g}$ with no signs of melanization were randomly selected for each group. A total of $5 \mu \mathrm{L}$ of the extract at doses of 1.0, 3.0, 7.0, 10.0 and $12.5 \mathrm{~g} / \mathrm{kg}$ or the control $(10 \% \mathrm{EtOH}, \mathrm{v} / \mathrm{v})$ (purity grade PA 99,5\%), were injected into the hemocoel of each larva via the last left proleg using a 25- $\mu$ L Hamilton syringe (Hamilton, Reno, NV). The larvae were incubated at $30^{\circ} \mathrm{C}$ and their survival was recorded at selected intervals for up to $72 \mathrm{~h}$, observing if there is a finding of changes such as the development of signs of melanization and a presence of touch immobilization. After this evaluation period, the larvae displaying no movements upon touch and with high levels of melanization were counted as dead. The dose that killed $50 \%$ of the sample was considered to be the $\mathrm{LD}_{50}$ and the dose capable of killing $100 \%$ of the larvae was considered the lethal dose.

\section{Statistical analysis}

The growth kinetics data were analyzed by one-way ANOVA followed by Tukey's post-hoc test in SPSS Statistical Program for Windows ${ }^{\circledR}$, version 20.0 (IBM, Chicago, USA). The cytotoxicity data were analyzed by one-way ANOVA followed by Dunnett's post-test. The values were expressed as mean \pm standard error of the mean (SEM) or standard deviation of the mean (SD). The in vivo toxicity data were analyzed using the Kaplan-Meier survival curve and estimates of differences in survival were compared using the log-rank test. The data were analyzed in GraphPad Prism 6.0 software (San Diego, CA, USA), with a $5 \%$ significance level.

\section{RESULTS}

\section{Phytochemical analysis}

The chemical characterization of Sc extract considered compounds with at least $\geq 40 \%$ probability as compared to the reference mass spectra present in the NIST library. As shown in Table No. 1 and Table No. 2, a total of 14 different compounds were identified, with polar and nonpolar characteristics.

\section{Antifungal activity}

S. cumini extract was tested for its inhibitory (MIC) and lethal (MFC) activity against Candida spp. The fungicidal or fungistatic capacity of the extract was characterized based on the MFC/MIC ratio, as shown in Table No. 3. The extract showed antifungal activity on all Candida spp. strains tested, with MIC values between 31.25 and $125 \mu \mathrm{g} / \mathrm{mL}$, and $\mathrm{MFC}$ values between $250 \mu \mathrm{g} / \mathrm{mL}$ and $\geq 1000 \mu \mathrm{g} / \mathrm{mL}$. Based on the MFC/MIC ratio (Siddiqui et al., 2013), Sc extract can be classified as fungistatic.

\section{Effects of Sc extract on C. albicans growth kinetics}

As shown in Figure No. 1, Sc extract significantly affected the growth kinetics of $C$. albicans after $8 \mathrm{~h}$ of treatment at different concentrations as compared to nystatin $(p=0.001)$. After $12 \mathrm{~h}$ and $24 \mathrm{~h}$, the extract no longer demonstrated growth inhibitory effects, with results similar to those observed in the negative control group $(p>0.05)$. The findings indicated that Sc extract has a fungistatic effect, particularly when in contact with $C$. albicans cells for at least $8 \mathrm{~h}$.

\section{Hemolytic potential of Sc extract on human erythrocytes}

As shown in Figure No. 2, the extract was able to cause concentration-dependent hemolysis of human erythrocytes. Similar results were also found when compared to the positive control (Table No. 4). Type $\mathrm{O}$ erythrocytes showed greater hemolytic susceptibility even at the lowest concentrations of the extract, whereas types $\mathrm{AB}$ and $\mathrm{O}$ erythrocytes were the most sensitive blood types at the highest tested concentrations of Sc extract, with higher percentages of cytotoxicity.

Analysis of osmotic fragility in human erythrocytes As shown in Figure No. 3, Sc extract was able to decrease hemolysis levels in human erythrocytes at lower concentrations, with statistically significant difference for most of the blood types and concentrations tested. Better results were found mainly on blood type B erythrocytes.

Antioxidant potential of Sc extract on human erythrocytes in the presence of reactive oxygen species

S. cumini extract was able to reduce the hemolytic 
percentage of erythrocytes exposed to $\mathrm{H}_{2} \mathrm{O}_{2}$, with a statistically significant difference $(p>0.0001)$ at the lowest concentrations $(31.25 \mu \mathrm{g} / \mathrm{mL}$ and 62.5 $\mu \mathrm{g} / \mathrm{mL}$ ), as shown in Figure No. 4. These findings indicate that Sc extract had an antioxidant effect on oxidative stress induced by $\mathrm{H}_{2} \mathrm{O}_{2}$. Interestingly, the results were relatively similar to those obtained with a standard antioxidant (Vitamin C) used as control in the assay.

Table No. 1

Identification of the compounds present in Syzygium cumini leaves extract by gas chromatography coupled to mass spectrometry (HP-5MS capillary column)

\begin{tabular}{|c|c|c|c|c|c|c|}
\hline PEAK & $\begin{array}{c}\text { RT } \\
(\mathbf{m i n})\end{array}$ & COMPOUND & CAS NUMBER & $\mathbf{P}(\%)$ & MF & MW \\
\hline 1 & 9.36 & 2,4-Dihydroxy-2,5-dimethyl-3(2H)-furan-3-one & $10230-62-3$ & 87.74 & $\mathrm{C}_{6} \mathrm{H}_{8} \mathrm{O}_{4}$ & 144 \\
\hline 2 & 17.86 & Thymine & $65-71-4$ & 65.32 & $\mathrm{C}_{5} \mathrm{H}_{6} \mathrm{~N}_{2} \mathrm{O}_{2}$ & 126 \\
\hline 3 & 19.41 & 3,3-Dimethylthietane & $13188-85-7$ & 67.50 & $\mathrm{C}_{5} \mathrm{H}_{10} \mathrm{~S}$ & 102 \\
\hline 4 & 19.47 & $\begin{array}{l}\text { 4H-Pyran-4-one,2,3-dihydro-3,5-dihydroxy-6- } \\
\text { methyl- }\end{array}$ & $28564-83-2$ & 93.09 & $\mathrm{C}_{6} \mathrm{H}_{8} \mathrm{O}_{4}$ & 144 \\
\hline 5 & 20.73 & Alpha-Terpineol & $98-55-5$ & 51.47 & $\mathrm{C}_{10} \mathrm{H}_{18} \mathrm{O}$ & 154 \\
\hline 6 & 21.98 & 5-Hydroxymethylfurfural & $67-47-0$ & 40.63 & $\mathrm{C}_{6} \mathrm{H}_{6} \mathrm{O}_{3}$ & 126 \\
\hline 7 & 26.19 & Phenol, 2,6-bis(1,1-dimethylethyl)- & $128-39-2$ & 40.17 & $\mathrm{C}_{14} \mathrm{H}_{22} \mathrm{O}$ & 206 \\
\hline 8 & 26.42 & Benzoic acid,4-ethoxy-,ethyl ester & $23676-09-7$ & 72.01 & $\mathrm{C}_{11} \mathrm{H}_{14} \mathrm{O}_{3}$ & 194 \\
\hline 9 & 28.13 & Ethyl $\alpha$-D-glucopyranoside & 19467-01-7 & 53.59 & $\mathrm{C}_{8} \mathrm{H}_{16} \mathrm{O}_{6}$ & 208 \\
\hline 10 & 31.17 & $\begin{array}{l}\text { 7,9-Di-tert-butyl-1-oxaspiro(4,5)deca-6,9-diene- } \\
\text { 2,8-dione }\end{array}$ & $82304-66-3$ & 64.36 & $\mathrm{C}_{17} \mathrm{H}_{24} \mathrm{O}_{3}$ & 276 \\
\hline 11 & 32.33 & Hexadecanoic acid,ethyl ester & $628-97-7$ & 47.02 & $\mathrm{C}_{18} \mathrm{H}_{36} \mathrm{O}_{2}$ & 284 \\
\hline 12 & 35.11 & Phytol & $150-86-7$ & 43.94 & $\mathrm{C}_{20} \mathrm{H}_{40} \mathrm{O}$ & 296 \\
\hline
\end{tabular}

Legend: R: Retention time; P: percentage of probability based on comparison with the mass spectra library; MF: molecular formula; MW: molecular weight)

Table No. 2

Identification of the compounds present in Syzygium cumini leaves extract by gas chromatography coupled to mass spectrometry (SPB - 624 column)

\begin{tabular}{c|c|c|c|c|c|c}
\hline PEAK & $\begin{array}{c}\text { RT } \\
(\mathbf{m i n})\end{array}$ & COMPOUND & CAS NUMBER & P (\%) & MF & MW \\
\hline 1 & 24.59 & 2,4-Dihydroxy-2,5-dimethyl-3(2H)-furan-3-one & $10230-62-3$ & 62.60 & $\mathrm{C}_{6} \mathrm{H}_{8} \mathrm{O}_{4}$ & 144 \\
\hline 2 & 24.92 & 2 -(5H)-furanone & $497-23-4$ & 60.25 & $\mathrm{C}_{4} \mathrm{H}_{4} \mathrm{O}_{2}$ & 84 \\
\hline 3 & 29.63 & $\begin{array}{c}4 \mathrm{H}-\text { pyran-4-one, 2,3-dihydro-3,5-dihydroxy-6- } \\
\text { methyl- }\end{array}$ & $28564-83-2$ & 94.17 & $\mathrm{C}_{6} \mathrm{H}_{8} \mathrm{O}_{4}$ & 144 \\
\hline 4 & 32.53 & 5-Hydroxymethylfurfural & $67-47-0$ & 89.15 & $\mathrm{C}_{6} \mathrm{H}_{6} \mathrm{O}_{3}$ & 126 \\
\hline 5 & 34.68 & Hydroquinone & $123-31-9$ & 40.73 & $\mathrm{C}_{6} \mathrm{H}_{6} \mathrm{O}_{2}$ & 110 \\
\hline
\end{tabular}

(Legend: R: Retention time; P: percentage of probability based on comparison with the mass spectra library; MF: molecular formula; MW: molecular weight) 

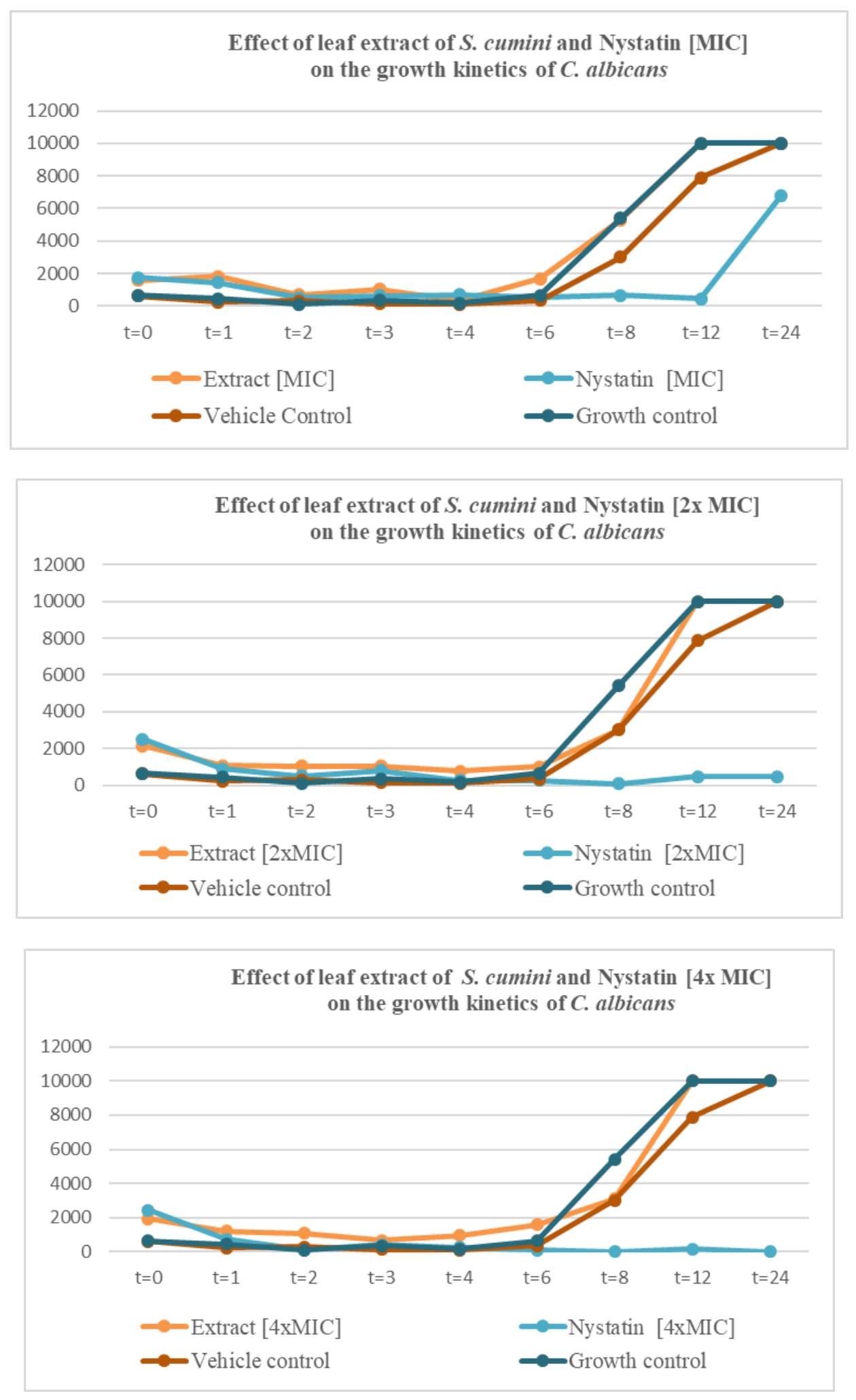

Figure No. 1

Effect of Syzygium cumini leaves extract and Nystatin on the growth kinetics of Candida albicans (ATCC 10231). The results are expressed as mean $\mathrm{CFU} / \mathrm{mL}$ Boletín Latinoamericano y del Caribe de Plantas Medicinales y Aromáticas / 543 
Blood Type A

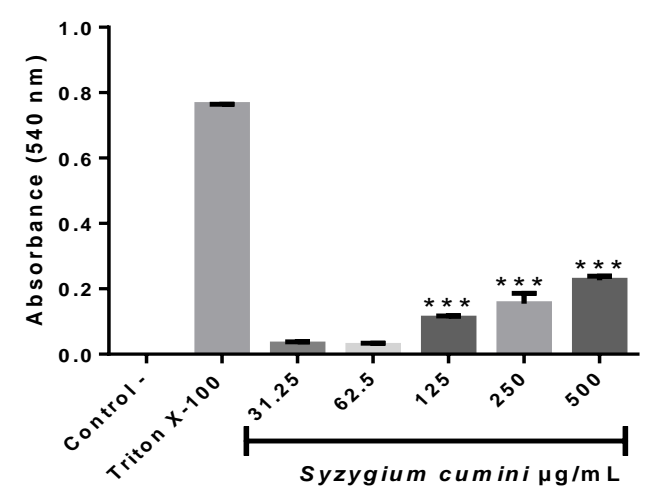

Blood Type AB

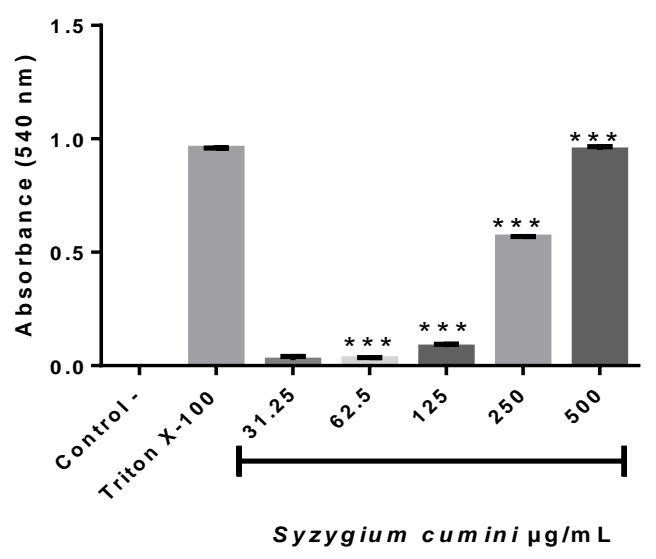

B lood Type B

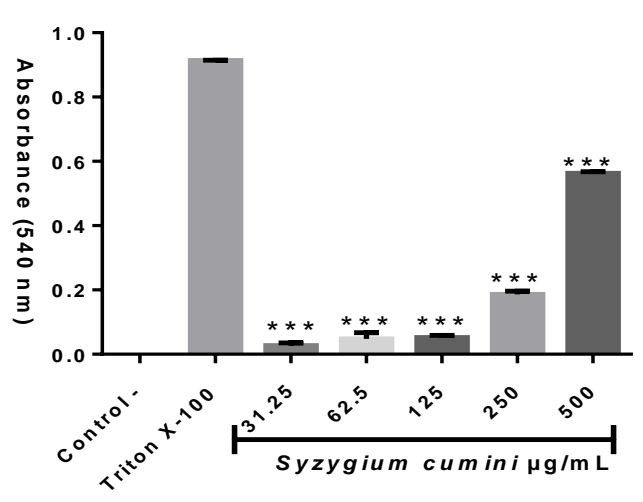

Blood Type 0

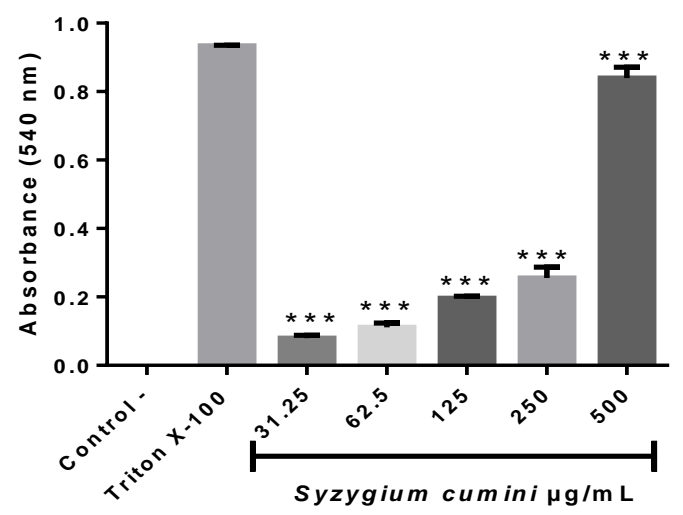

Figure No. 2

Hemolytic effects of Syzygium cumini leaves extract on human erythrocytes of blood types A, B, AB and O as compared to the negative control. The results are expressed as mean \pm SEM. Analysis by one-way ANOVA followed by Dunnett's post-test. $\left({ }^{*} p<0.05 ; * * p<0.001 ; * * * p<0.0001\right)$ 
Table No. 3

Antifungal activity of the Syzygium cumini leaves extract and standard drugs on Candida spp. strains

\begin{tabular}{|c|c|c|c|c|c|c|c|c|c|}
\hline \multirow[b]{2}{*}{ Strain } & \multicolumn{3}{|c|}{ Sc } & \multicolumn{3}{|c|}{ NYS } & \multicolumn{3}{|c|}{ FLU } \\
\hline & $\begin{array}{c}\mathrm{MIC} \\
(\mu \mathrm{g} / \mathrm{ml})\end{array}$ & $\begin{array}{c}\mathrm{MFC} \\
(\mu \mathrm{g} / \mathrm{ml})\end{array}$ & $\begin{array}{c}\mathrm{MFC} / \mathrm{M} \\
\mathrm{IC}\end{array}$ & $\begin{array}{c}\mathrm{MIC} \\
(\mu \mathrm{g} / \mathrm{ml})\end{array}$ & $\begin{array}{c}\mathrm{MFC} \\
(\mu \mathrm{g} / \mathrm{ml})\end{array}$ & $\begin{array}{c}\mathrm{MFC} / \mathrm{MI} \\
\mathrm{C}\end{array}$ & $\begin{array}{c}\mathrm{MIC} \\
(\mu \mathrm{g} / \mathrm{ml})\end{array}$ & $\begin{array}{c}\mathrm{MFC} \\
(\mu \mathrm{g} / \mathrm{ml})\end{array}$ & $\begin{array}{c}\mathrm{MFC} / \mathrm{MI} \\
\mathrm{C}\end{array}$ \\
\hline $\begin{array}{c}\text { C. albicans } \\
\text { (ATCC 10231) }\end{array}$ & 125 & 1000 & 8 & 4 & 64 & 16 & 32 & $>64$ & $>2$ \\
\hline $\begin{array}{c}\text { C. glabrata } \\
(\text { ATCC 90030) }\end{array}$ & 62.5 & $>1000$ & $>16$ & 2 & 64 & 32 & $>64$ & $>64$ & $>1$ \\
\hline $\begin{array}{c}\text { C. albicans (ATCC } \\
\text { 10231) + C. } \\
\text { glabrata (ATCC } \\
90030)\end{array}$ & 125 & 1000 & 8 & 4 & 32 & 8 & $>64$ & $>64$ & $>1$ \\
\hline $\begin{array}{c}\text { C. krusei } \\
\text { (ATCC 6258) }\end{array}$ & 31.25 & 250 & 8 & $>64$ & $>64$ & $>1$ & $>64$ & $>64$ & $>1$ \\
\hline $\begin{array}{l}\text { C. tropicalis } \\
\text { (ATCC 750) }\end{array}$ & 62.5 & $>1000$ & $>16$ & 4 & $>64$ & $>16$ & 8 & $>64$ & $>8$ \\
\hline C. albicans (LM 01) & 31.25 & 1000 & 32 & 4 & 16 & 4 & 64 & $>64$ & $>1$ \\
\hline C. albicans (LM 03) & 31.25 & $>1000$ & $>32$ & 2 & $>64$ & $>32$ & 32 & $>64$ & $>2$ \\
\hline
\end{tabular}

(Legend: Sc: Syzygium cumini extract; NYS: Nystatin; FLU: Fluconazole; MIC: Minimum inhibitory concentration; MFC: Minimum Fungicidal Concentration; MFC/MIC: MFC/MIC ratio)

Table No. 4

Percentage of hemolysis caused by Syzygium cumini leaves extract on human erythrocytes of blood types A, $\mathrm{B}, \mathrm{AB}$ and $\mathrm{O}$, as compared to the positive control (1\% Triton $\mathrm{X}-100)$

\begin{tabular}{|c|c|c|c|c|c|}
\hline \multirow[t]{2}{*}{ Sc extract concentration } & \multicolumn{5}{|c|}{ \% hemolysis } \\
\hline & $\begin{array}{r}31.25 \\
\mu \mathrm{g} / \mathrm{mL}\end{array}$ & $\begin{array}{c}62.5 \\
\mu \mathrm{g} / \mathrm{mL}\end{array}$ & $\begin{array}{c}125 \\
\mu \mathrm{g} / \mathrm{mL}\end{array}$ & $\begin{array}{c}250 \\
\mu \mathrm{g} / \mathrm{mL}\end{array}$ & $\begin{array}{c}500 \\
\mu \mathrm{g} / \mathrm{mL}\end{array}$ \\
\hline $\mathbf{A}$ & 4.0 & 3.5 & 14.4 & 20.1 & 29.5 \\
\hline B & 2.8 & 5.2 & 5.7 & 20.0 & 61.0 \\
\hline $\mathbf{A B}$ & 2.5 & 3.1 & 8.4 & 59.0 & 99.1 \\
\hline $\mathbf{O}$ & 8.0 & 11.0 & 23.0 & 27.0 & 89.0 \\
\hline
\end{tabular}

Boletín Latinoamericano y del Caribe de Plantas Medicinales y Aromáticas / 545 

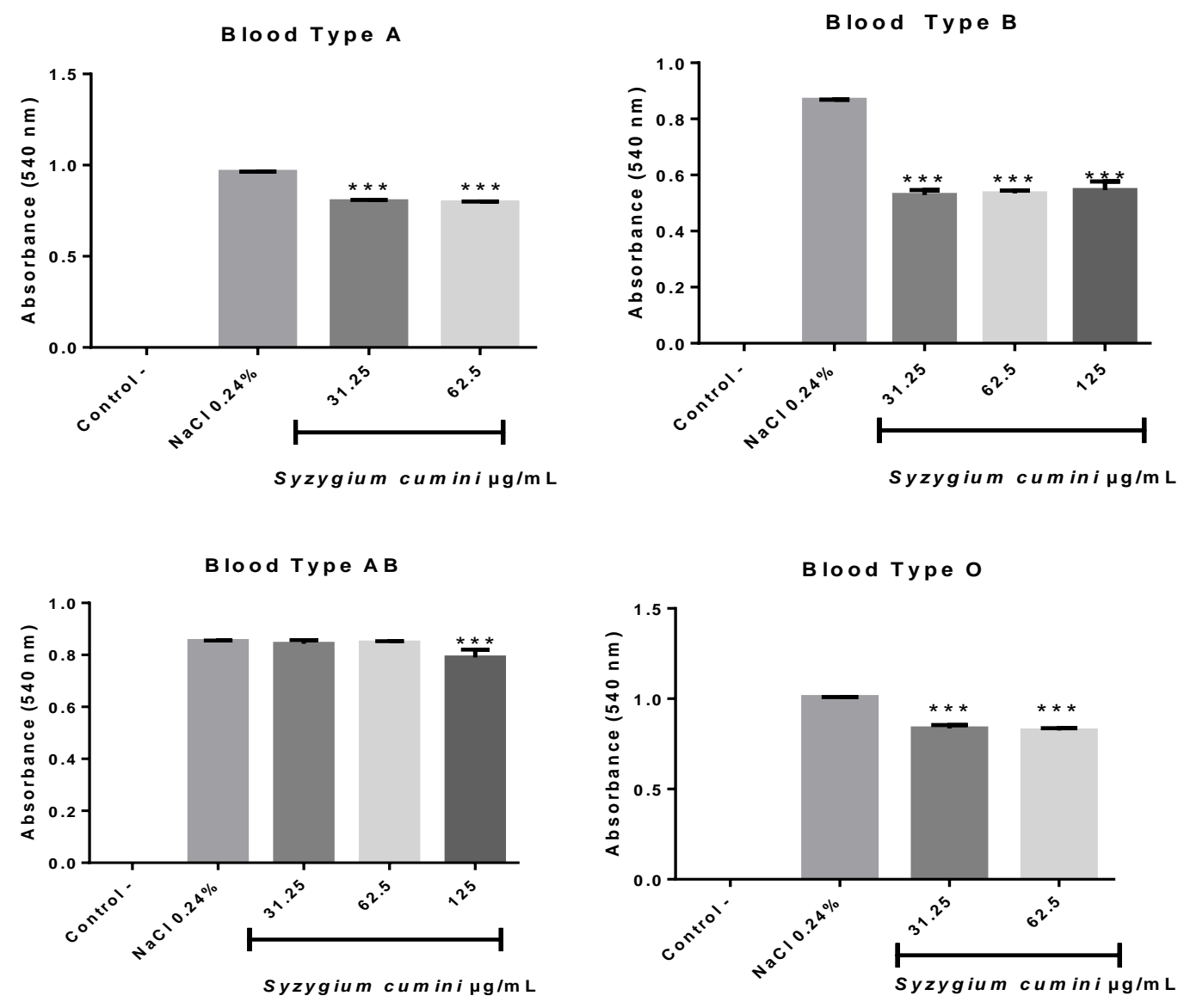

Figure No. 3

Anti-hemolytic effects of Syzygium cumini leaves extract on human erythrocytes of blood types A, B, AB and $O$ in hypotonic solution $(0.24 \% \mathrm{NaCl})$. The results were compared to the positive control and are expressed as mean \pm SEM. Analysis by one-way ANOVA followed by Dunnett's post-test $(* p<0.05 ; * * p<0.001$; $* * * p<0.0001)$ 


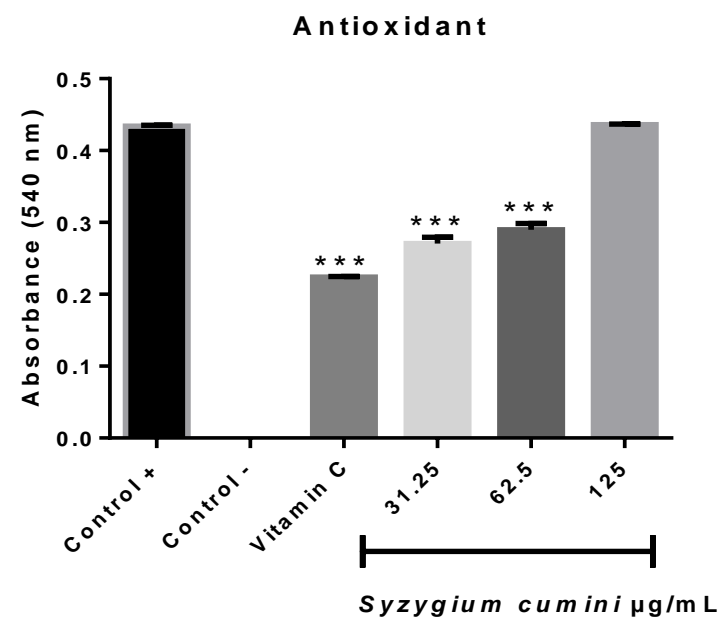

Figure No. 4

Antioxidant effects of Syzygium cumini leaves extract on hemolysis induced by hydrogen peroxide in human erythrocytes of blood type $\mathrm{AB}$. The results were compared to the positive control and are expressed as mean \pm SEM. Analysis by one-way ANOVA followed by Dunnett's post-test $\left(*^{*}<<0.05 ; * * p<0.001 ; * * * p<0.0001\right)$
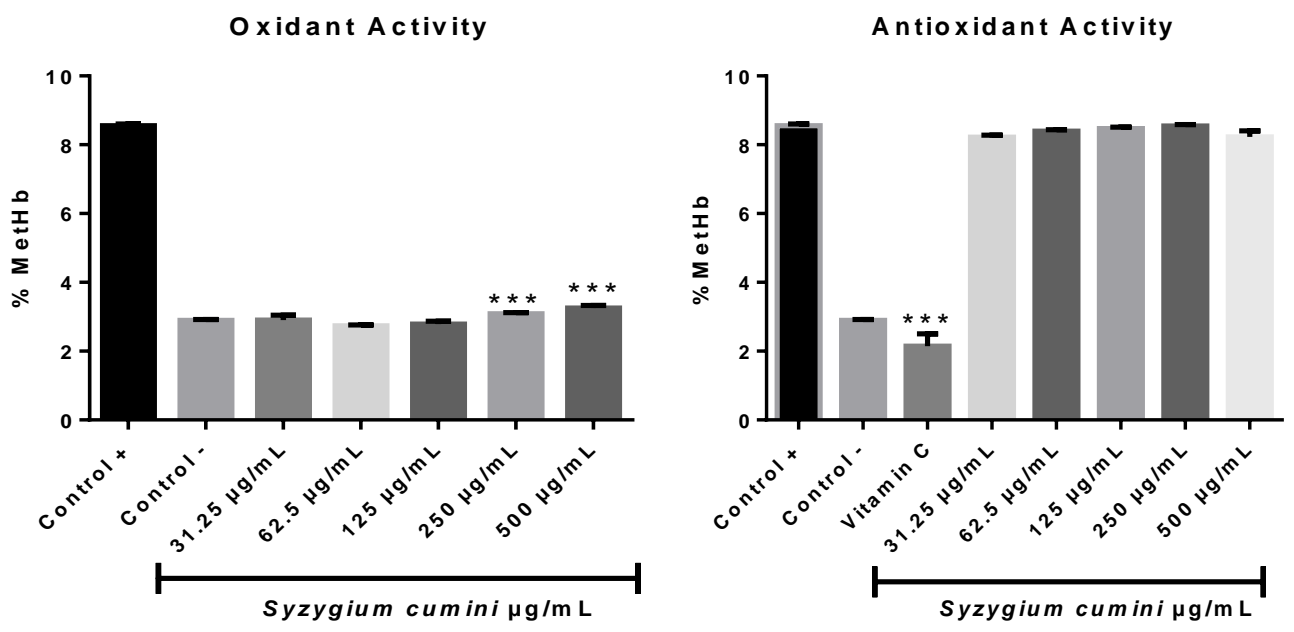

Figure No. 5

Oxidant and antioxidant effects of Syzygium cumini leaves extract on on human erythrocytes of blood type AB. The results were expressed as the mean percentage of metHb formation as compared to the negative (oxidant assay) and positive (antioxidant assay) controls. Analysis by one-way ANOVA followed by Dunnett's post-test. $(* p<0.05 ; * * p<0.001 ; * * * p<0.0001)$ 


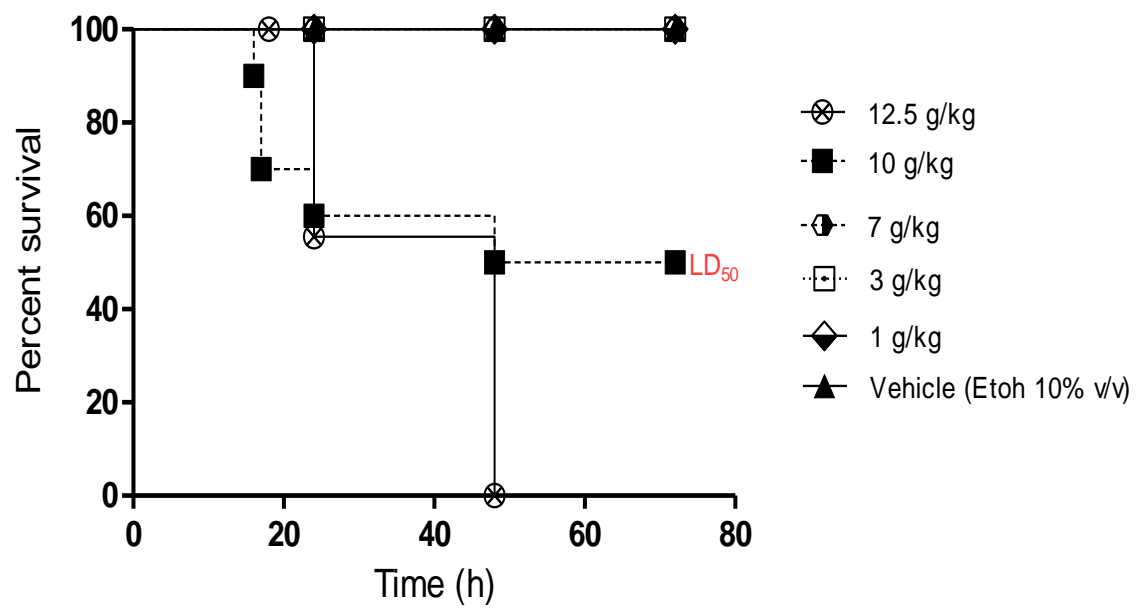

Figure No. 6

In vivo acute systemic toxicity of $S$. cumini leaves extract in Galleria mellonella larvae. The graph shows a survival curve of larvae treated with the extract at different concentrations, or dilution vehicle, over time ( $p>0.05$, Log-rank test)

\section{Oxidant and antioxidant potential of Sc extract on human erythrocytes in the presence of phenylhydrazine}

The percentages of methemoglobin (MetHb) and hemoglobin $(\mathrm{Hb})$ were quantitated upon erythrocyte exposure to $\mathrm{Sc}$ extract and phenylhydrazine. As shown in Figure No. 5, Sc extract was capable to promote oxidation of $\mathrm{Hb}$ into metHb only at the highest concentrations tested as compared to the negative control. At concentrations equal to, or lower than, $125 \mu \mathrm{g} / \mathrm{mL}$, Sc extract did not induce the occurrence of $\mathrm{Hb}$ oxidation in human erythrocytes.

On the other hand, the antioxidant activity test (Figure No. 5) showed that, as compared to the results obtained with phenylhydrazine, the metHb/Hb formation levels induced by the erythrocytes exposed to the positive control and treated later with Sc extract were not significantly reduced. These findings suggest that Sc extract does not have a protective effect in cells previously exposed to phenylhydrazine-induced oxidative reactions.

\section{In vivo toxicity in Galleria mellonella systemic model}

S. cumini extract was tested for its in vivo toxicity in a systemic model of $G$. mellonella larvae. The extract showed low toxicity on the larvae (Figure No. 6) when administered at doses up to $7 \mathrm{~g} / \mathrm{kg}(p>0.05)$, with no significant difference when compared to the dilution vehicle $(10 \% \mathrm{EtOH}, \mathrm{v} / \mathrm{v})(p>0.05)$. At the doses of $10 \mathrm{~g} / \mathrm{kg}\left(\mathrm{LD}_{50}\right)$ and $12.5 \mathrm{~g} / \mathrm{kg}$, Sc extract affected the viability of the larvae, killing $50 \%$ and $100 \%$ of the larvae, respectively $(p<0.0001)$.

\section{DISCUSSION}

The alarmingly high microbial resistance rates to current antifungals (Doi et al., 2016; Gulati \& Nobile, 2016; Savastano et al., 2016) has reinforced the need for discovery of new substances with pharmacological potential (Coleman et al., 2010; Pereira et al., 2016), which includes those from medicinal plants, such as $S$. cumini.

Different secondary metabolites are responsible for the biological effects of medicinal plants (De Araújo et al., 2018). Consistent with this, the literature has related the antimicrobial activity of extracts with the presence of phenolic compounds (Harsha \& Anilakumar, 2014; Cartaxo-Furtado et al., 2015), flavonoids (Cartaxo-Furtado et al., 2015) and tannins (Gowri \& Vasantha, 2010; Cartaxo-Furtado et al., 2015). Moreover, phenolic compounds (Evensen \& Braun, 2009), flavonoids (Pereira et al., 2016) and saponins (Coleman et al., 2010; Gowri \& Vasantha, 2010; Pereira et al., 2016) been reported as having antifungal activity.

Thus, the antimicrobial activity of $S$.

\section{Boletín Latinoamericano y del Caribe de Plantas Medicinales y Aromáticas / 548}


cumini leaves extract can be attributed to bioactive compounds present in its composition, including saponins, phenolic compounds, tannins and flavonoids, since they were preliminarily identified in its composition (Pereira et al., 2016). However, the chromatographic identification carried out in the present study provided additional details on the chemical composition of Sc extract, including the determination of the probable major compounds responsible for the pharmacological activity of the extract. Among the compounds detected in Sc extract and their respective biological activity are: antimicrobial and antifungal activity of 4H-Pyran-4one, 2,3-dihydro-3,5-dihydroxy-6-methyl, a flavonoid compound (Gopalakrishnan \& Udayakumar, 2014; Sunita \& Manju, 2017; Teoh \& Don, 2014; Teoh et al., 2011; Peng \& Don, 2013); antimicrobial activity of Benzoic acid, 4-ethoxy-, ethyl ester, an aromatic acid ester (Daffodil et al., 2012); 7,9-Di-tert-butyl-1-oxaspiro[4.5]deca-6,9diene-2,8-dione, a flavonoid compound (Sharif et al., 2015; Sunita \& Manju, 2017); 2-(5H)-furanone, a terpene compound (Trizna et al., 2015; Sharafutdinov et al., 2017); alpha-terpineol (Mahdavi et al., 2017), a monoterpenoid compound (Satyal et al, 2017); hexadecanoic acid, ethyl ester, a polyphenolic compound (Sharma et al., 2018) and hydroquinone, a phenolic compound (Jyoti et al., 2016; Gutiérrez et al., 2017; Żbikowska et al., 2017); and antifungal activity of alpha-terpineol (Satyal et al., 2017). The presence of these substances in $S$. cumini extract suggest that the biological effects attributed to these compounds may be responsible for the potentially promising antimicrobial activity of the extract.

Based on its MIC values, Sc extract showed an active antimicrobial potential (MIC < $1000 \mu \mathrm{g} / \mathrm{mL}$ ) (Holetz et al., 2002; Morales et al., 2008) on all tested Candida spp. strains, more specifically a moderate (MIC: $100-500 \mu \mathrm{g} / \mathrm{mL}$ ) to high (MIC $<100 \mu \mathrm{g} / \mathrm{mL}$ ) activity (Holetz et al., 2002; Morales et al., 2008), depending on the strain. The MFC/MIC ratio indicated a fungistatic activity of Sc extract (MFC/MIC $\geq 4$ ) (Siddiqui et al., 2013) on all Candida ssp strains.

Remarkably, some Candida strains tested in our study were found to be less susceptible to fluconazole treatment, which is consistent with current microbial resistance reports (Doi et al., 2016; Gulati \& Nobile, 2016; Savastano et al., 2016).In addition, the combination of $C$. albicans (ATCC
10231) and C. glabrata (ATCC 90030) cultures was less susceptible to the action of Sc extract and fluconazole, which suggests that coinfection plays a significant role in microbial resistance to antimicrobials such as fluconazole (Gomes et al., 2011; Savastano et al., 2016), miconazole, itraconazole and amphotericin B (Savastano et al., 2016).

S. cumini extract had inhibitory activity against Candida spp., which confirmed the first hypothesis of this study. The extract was also tested for its in vitro cytotoxicity in human erythrocytes and in vivo toxicity in Galleria mellonella larvae. The hemolytic activity test used herein has been widely reported in the literature to investigate the cytotoxic potential of chemical substances (Tupe et al., 2015; Mehreen et al., 2016; Vo et al., 2017; De Araújo et al., 2018; Lira et al., 2018; Figueirêdo Júnior et al., 2019). To complement the analysis of hemolysis, we further carried out an osmotic fragility assay (He et al., 2009; Waczuk et al., 2015; Duarte et al., 2016; De Araújo et al., 2018; Lira et al., 2018; Figueirêdo Júnior et al., 2019). To the best of our knowledge, this is the first study using these in vitro and in vivo toxicological models to determine the toxicity of Sc extract.

The results of these tests suggest that $\mathrm{Sc}$ extract had a low hemolytic activity $(<40 \%$ hemolysis) as compared to the positive control for most of the concentrations tested. At the highest concentrations, however, the hemolytic activity of Sc extract ranged from moderate (40-80\% hemolysis) to high (> $80 \%$ hemolysis) depending on the blood type (Rangel et al., 1997). At antifungal concentrations (MIC $\leq 125 \mu \mathrm{g} / \mathrm{mL}$ ), Sc extract demonstrated low hemolytic activity on human erythrocytes of all blood types. Hence, Sc extract cytotoxicity seems to be negligible at these concentrations, which is desirable for future clinical use.

Hemolysis caused by Sc extract at higher concentrations may be a result of the presence of phytochemical compounds such as saponins, which are known to display hemolyzing properties (Coleman et al., 2010). In this context, as erythrocytes contain high concentrations of polyunsaturated fatty acids, molecular oxygen and ions linked in the ferrous state (Lira et al., 2018), these cells are affected by reactive oxygen species due to high cell concentration of oxygen and hemoglobin $(\mathrm{Hb})$ and the absence of cellular 
components to synthesize new proteins (Carl et al., 2016). So, since erythrocytes undergo structural and functional changes causing dysfunction of the cationic pumps due to oxidative modifications in lipids and membrane proteins, which can destabilize them (Carl et al., 2016), the occurrence of hemolysis can be justified by reactions involving free radicals which making the cells susceptible to lipid peroxidation in cell membranes (Lira et al., 2018). The differences in the hemolytic levels indicated blood-type related cytotoxicity of Sc extract. This fact could be justified by differences in carbohydrate structures present on some membrane glycoproteins and glycolipids of erythrocytes from hosts with different blood types in the ABO system. (Batissoco, Novaretti, 2003; Daniels, 2009; Paiva et al., 2009; Carl et al., 2016). These diferences are attributed to antigenic variability denominated antigens A and B synthesized by glycosyltransferases that catalyze the addition of specific monosaccharides to the precursor, denominated $\mathrm{H}$ antigen (Batissoco, Novaretti, 2003; Daniels, 2009; Paiva et al., 2009; Carl et al., 2016). Thus, the pertinent considerations regarding the chemical composition of the extract and the inherent differences in the erythrocytes of the different blood groups may justify the variations observed in the hemolytic profiles induced by $\mathrm{Sc}$ extract.

The evaluation of the anti-hemolytic activity of Sc extract allowed to estimate that at certain concentrations and depending on the blood type, it exerts a protective effect on the cell membrane of erythrocytes exposed to osmotic stress (He et al., 2009; Waczuk et al., 2015; Duarte et al., 2016; Figueirêdo Júnior et al., 2019). This effect could be evidenced by the reduced percentage of cellular damage in cells previously treated with Sc extract. Taken altogether, the results of the hemolysis and osmotic fragility tests revealed that Sc extract may have a dual role either inducing or protecting from cell membrane damage depending on the concentration used.

The need to investigate new substances with antioxidant activity (Mohamed et al., 2013; Lira et al., 2018; Figueirêdo Júnior et al., 2019) encouraged us to determine the antioxidant potential of Sc extract. The findings of our study suggest that, at low concentrations, Sc extract may be beneficial by acting as an antioxidant agent against hydrogen peroxideinduced oxidative challenge (Mohamed et al., 2013;
Harsha \& Anilakumar, 2014; Figueirêdo Júnior et al., 2019).

Phenolic compounds (Mohamed et al., 2013; Harsha \& Anilakumar, 2014; Lira et al., 2018), flavonoids (Mohamed et al., 2013; Harsha \& Anilakumar, 2014), terpenes (Santos et al., 2013) and saponins (Gowri \& Vasantha, 2010) have been reported to have antioxidant activity and may explain the antioxidant properties of Sc extract observed in our study. However, the chemical compounds identified in the chromatographic analysis may also play a role in the antioxidant activity of Sc extract, including 4H-pyran-4-one, 2,3-dihydro-3,5dihydroxy-6-methyl- (Čechovská et al., 2011; Teoh et al., 2011; Peng \& Don, 2013; Gopalakrishnan \& Udayakumar, 2014), a flavonoid compound (Gopalakrishnan \& Udayakumar, 2014); 5Hydroxymethylfurfural (Kim et al., 2011; Zhao et al., 2013; Li et al., 2015; Mopuri et al., 2018), an intermediate produced through the degradation of hexoses and the Maillard reaction (Zhao et al, 2013); 2,4-Dihydroxy-2,5-dimethyl-3(2H)-furan-3-one, a furan ketone (Gopalakrishnan \& Udayakumar, 2014); phytol (Santos et al., 2013; Jorge et al., 2017), a diterpene compound (Santos et al., 2013; Gopalakrishnan \& Udayakumar, 2014; Jorge et al, 2017) and hydroquinone (Erenler et al., 2016) a phenolic compound (Gutiérrez et al., 2017). Thus, the presence of these molecules of different families can direct and justify the antioxidant properties of Sc extract.

The toxicological findings obtained in our study partially confirmed the second hypothesis that the extract is biologically compatible with human erythrocytes. While a thorough toxicological assessment in other relevant in vivo models is pending, the results obtained in the present study support the evidence that Sc extract has low toxicity against other cell lines, such as human keratinocytes and murine macrophages (Pereira et al., 2016). Thus, these results suggest that at antifungal concentrations, $S$. cumini extract demonstrated low cytotoxicity in different cell lines.

We further determined the toxicity of Sc extract using a well-known, validated in vivo model (Megaw et al., 2015; Rochelle et al., 2016; Sardi et al., 2017; Allegra et al., 2018), which indicated a negligible toxicity of the extract upon systemic administration in G. mellonella larvae. In this model, the $\mathrm{LD}_{50}$ of the extract was extremely high values

\section{Boletín Latinoamericano y del Caribe de Plantas Medicinales y Aromáticas / 550}


$(500.000 \mu \mathrm{g} / \mathrm{mL})$, i.e. $4.000-160.000$ times greater than its MIC values against planktonic cells (depending on the fungal strains), as verified in the microbiological tests. In addition, it is important to consider that such concentration is $1.000 \mathrm{x}$ greater than that capable of effectively disrupting Candida albicans biofilms $(500 \mu \mathrm{g} / \mathrm{mL})$, as previously described (Pereira et al., 2016). Thus, the in vivo analysis in $G$. mellonella suggests a large margin of safety for the use of the extract at antifungal concentrations against planktonic or biofilm Candida spp. These findings confirm the third hypothesis tested in this study that under these conditions Sc extract does not promote toxicity in G. mellonella larvae.

Taken altogether, the findings of this study support the view that further research should focus on other toxicological assays like acute and chronic toxicological screening and mutagenic activity of Sc leaves extract using other relevant in vivo and in silico (if applicable) models.

\section{CONCLUSION}

The present study demonstrated that the leaf extract of $S$. cumini has various substances associated with antimicrobial effects. S. cumini extract has promising antifungal activity on Candida spp. and showed a fungistatic activity, with significant inhibitory effects on $C$. albicans growth kinetics. In terms of toxicity, the extract showed low cytotoxicity against human erythrocytes when used at antifungal concentrations, as well as low hemolytic activity and protective effects against osmotic stress-induced hemolysis. The extract did not oxidize hemoglobin in erythrocytes and displayed antioxidant activity at low concentrations upon hydrogen peroxide-induced stress. Lastly, the extract showed a very large margin of safety in an in vivo invertebrate model of systemic toxicity. Taken altogether, the findings of our study provide evidence on the effects of $S$. cumini leaves extract as an alternative antifungal agent. Further research should investigate whether the biological activity of the extract is due to the presence of specific compounds or to the mixed, complex combination of phytochemicals present therein. Moreover, further studies should focus on the toxicological parameters of the extract for future clinical use in relevant mammal and in silico (if applicable) models.

\section{ACKNOWLEDGEMENTS}

This study was supported by the Coordination for the Improvement of Higher Education Personnel (CAPES) through a scholarship.

\section{REFERENCES}

Allegra E, Titball RW, Carter J, Champion OL. 2018. Galleria mellonella larvae allow the discrimination of toxic and non-toxic chemicals. Chemosphere 198: 469 - 472.

https://doi.org/10.1016/j.chemosphere.2018.01.175

Ayyanar M, Subash-Babu P. 2012. Syzygium cumini (L.) Skeels: A review of its phytochemical constituents and traditional uses. Asian Pac J Trop Biomed 2: 240 - 246. https://doi.org/10.1016/S2221-1691(12)60050-1

Baliga MS, Fernandes S, Thilakchand KR, D'souza P, Rao S. 2013. Scientific validation of the antidiabetic effects of Syzygium jambolanum DC (black plum), a traditional medicinal plant of India. J Altern Complement Med 19: 191 - 197. https://doi.org/10.1089/acm.2011.0752

Batissoco AC, Novaretti MCZ. 2003. Aspectos moleculares do sistema sangüíneo ABO. Rev Bras Hematol Hemoter 25: 47 - 58. https://doi.org/10.1590/S1516-84842003000100008 .

Cantón E, Pemán J, Valentín A, Espinel-Ingroff A, Gobernado M. 2009. In vitro activities of echinocandins against Candida krusei determined by three methods: MIC and minimal fungicidal concentration measurements and time-kill studies. Antimicrob Agents Chemother 53: 3108 - 3111.

https://doi.org/10.1128/AAC.00160-09

Cartaxo-Furtado NADEO, Sampaio TO, Xavier MA, Medeiros ADDE, Pereira JV. 2015. Perfil fitoquímico e determinação da atividade antimicrobiana de Syzygium cumini (L.) Skeels (Myrtaceae) frente a microrganismos bucais. Rev Bras Plant Med 17: 1091 - 1096. https://doi.org/10.1590/1983-084X/14_153

Carl H, Soumya R, Srinivas P, Vani R. 2016. Oxidative stress in erythrocytes of banked ABO blood. Hematology 21: 630 - 634. https://doi.org/10.1080/10245332.2016.1187824

Čechovská L, Cejpek K, Konečný M, Velíšek J. 2011. On the role of 2,3-dihydro-3,5-dihydroxy-6-methyl-(4H)- 
pyran-4-one in antioxidant capacity of prunes. Eur Food Res Technol 233: 367 - 376. https://doi.org/10.1007/s00217-011-1527-4

Chagas VT, França LM, Malik S, Paes AM. 2015. Syzygium cumini (L.) skeels: A prominent source of bioactive molecules against cardiometabolic diseases. Front Pharmacol 6: 259. https://doi.org/10.3389/fphar.2015.00259

CLSI (2008). [Clinical and Laboratory Standards Institute]. Method for broth dilution antifungal susceptibility testing of yeasts: approved standard-third edition M27-A3. Wayne, Pensylvânia, USA.

Coleman JJ, Okoli I, Tegos GP, Holson EB, Wagner FF, Hamblin MR, Mylonakis E. 2010. Characterization of plant-derived saponin natural products against Candida albicans. ACS Chem Biol 5: 321 - 332. https://doi.org/10.1021/cb900243b

Daffodil ED, Uthayakumari FK, Mohan VR. 2012. GC-MS determination of bioactive compounds of Curculigo Orchioides Gaertn. Sci Res Rep 2: 198 - 201.

Daniels G. 2009. The molecular genetics of blood group polymorphism. Hum Genet 126: 729 - 742. https://doi.org/10.1007/s00439-009-0738-2

De Araújo JSC, de Castilho ARF, Lira AB, Pereira AV, de Azevêdo TKB, de Brito Costa E MM, Pereira MSV, Pessoa HFL, Pereira JV. 2018. Antibacterial activity against cariogenic bacteria and cytotoxic and genotoxic potential of Anacardium occidentale L. and Anadenanthera macrocarpa (Benth.) Brenan extracts. Arch Oral Biol 85: 113 - 119. https://doi.org/10.1016/j.archoralbio.2017.10.008

De Castro RD, Lima EO, Freires IA, Alves LA. 2013. Combined effect of Cinnamomum zeylanicum blume essential oil and nystatin on Candida albicans growth and micromorphology. Rev Ciênc Méd Biol 12: 149 $-156$.

Doi AM, Pignatari AC, Edmond MB, Marra AR, Camargo LFA, Siqueira RA, da Mota VP, Colombo AL. 2016. Epidemiology and microbiologic characterization of nosocomial candidemia from a brazilian national surveillance program. PLoS One 11: e0146909. https://doi.org/10.1371/journal.pone.0146909

Duarte AE, Waczuk EP, Roversi K, Da Silva MAP, Barros LM, Da Cunha FAB, De Menezes IRA, Da Costa JGM, Boligon AA, Ademiluyi AO, Kamdem JP, Rocha JBT, Burger ME. 2016. Polyphenolic composition and evaluation of antioxidant activity, osmotic fragility and cytotoxic effects of Raphiodon echinus (Nees \& Mart.) schauer. Molecules 21: E2. https://doi.org/10.3390/molecules21010002

Erenler R, Sen O, Aksit H, Demirtas I, Yaglioglu AS, Elmastas M, Telci I. 2016. Isolation and identification of chemical constituents from Origanum majorana and investigation of antiproliferative and antioxidant activities. J Sci Food Agric 96: 822 - 836. https://doi.org/10.1002/jsfa.7155

Evensen NA, Braun PC. 2009. The effects of tea polyphenols on Candida albicans: Inhibition of biofilm formation and proteasome inactivation. Can J Microbiol 55: 1033 - 1039. https://doi.org/10.1139/W09-058

Figueirêdo Júnior EC, Costa BP, Freire JCP, Melo WOS, Pessôa HLF, Gomes DQC, Costa EMMB, Pereira JV. 2019. Use of erythrocytes in cytotoxicity and toxicity assays of medicinal plant extracts: analysis of their application and bibliometric study. Bol Latinoam Caribe Plant Med Aromat 18: 359 - 377.

Gomes PN, da Silva WJ, Pousa CC, Narvaes EA, Del Bel Cury AA. 2011. Bioactivity and cellular structure of Candida albicans and Candida glabrata biofilms grown in the presence of fluconazole. Arch Oral Biol 56: 1274 - 1281. https://doi.org/10.1016/j.archoralbio.2011.04.006

Gopalakrishnan K, Udayakumar R. 2014. GC-MS analysis of phytocompounds of leaf and stem of Marsilea quadrifolia (L.). Int J Biochem Res Rev 4: 517 - 526.

Gowri SS, Vasantha K. 2010. Phytochemical screening and antibacterial activity of Syzygium cumini (L.) (Myrtaceae) leaves extracts. Int J Pharm Tech Res 2: 1569 - 1573.

Gulati M, Nobile CJ. 2016. Candida albicans biofilms: development, regulation, and molecular mechanisms. Microbes Infect 18: 310 - 321. https://doi.org/10.1016/j.micinf.2016.01.002

Gutiérrez S, Morán A, Martínez-Blanco H, Ferrero MA, Rodríguez-Aparicio LB. 2017. The usefulness of non-toxic plant metabolites in the control of bacterial proliferation. Probiotics Antimicrob Prot 9: 323 - 333. https://doi.org/10.1007/s12602-017-9259-9

Harsha SN, Anilakumar KR.2014. In vitro free radical scavenging and DNA damage protective property of Coriandrum sativum L. leaves extract. J Food Sci Technol 51: 1533 - 1539.

Boletín Latinoamericano y del Caribe de Plantas Medicinales y Aromáticas / 552 
https://doi.org/10.1007/s13197-012-0648-5

He J, Lin J, Li J, Zhang JH, Sun XM, Zeng CM. 2009. Dual effects of Ginkgo biloba leaf extract on human red blood cells. Basic Clin Pharmacol Toxicol 104: 138 - 144.

https://doi.org/10.1111/j.1742-7843.2008.00354.x

Höfling JF, Anibal PC, Obando-Pereda GA, Peixoto IAT, Furletti VF, Foglio MA, Gonçalves RB. 2010. Antimicrobial potential of some plant extracts against Candida species. Braz J Biol 70: 1065 - 1068. https://doi.org/10.1590/S1519-69842010000500022

Holetz FB, Pessini GL, Sanches NR, Cortez DAG, Nakamura CV, Dias Filho BP. 2002.Screening of some plants used in the brazilian folk medicine for the treatment of infectious diseases. Mem Inst Oswaldo Cruz 97: 1027 - 1031. https://doi.org/10.1590/S0074-02762002000700017

Jorge LF, Meniqueti AB, Silva RF, Santos KA, Da Silva EA, Gonçalves JE, De Rezende CM, Colauto NB, Gazim ZC, Linde GA. 2017. Antioxidant activity and chemical composition of oleoresin from leaves and flowers of Brunfelsia uniflora. Genet Mol Res 16: https://doi.org/10.4238/gmr16039714

Jyoti MA, Nam KW, Jang WS, Kim YH, Kim SK, Lee BE, Song HY. 2016. Antimycobacterial activity of methanolic plant extract of Artemisia capillaris containing ursolic acid and hydroquinone against Mycobacterium tuberculosis. J Infect Chemother 22: 200 - 208.

https://doi.org/10.1016/j.jiac.2015.11.014

Kim HK, Choi YW, Lee EN, Park JK, Kim SG, Park DJ, Kim BS, Lim YT, Yoon S. 2011. 5Hydroxymethylfurfural from black garlic extract prevents TNF $\alpha$-induced monocytic cell adhesion to HUVECs by suppression of vascular cell adhesion molecule-1 expression, reactive oxygen species

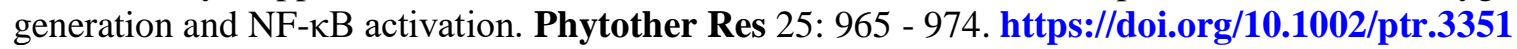

Klepser ME, Wolfe EJ, Jones RN, Nightingale CH, Pfaller MA.1997. Antifungal pharmacodynamic characteristics of fluconazole and amphotericin B tested against Candida albicans. Antimicrob Agents Chemother 41: 1392 - 1395.

Li W, Qu XN, Han Y, Zheng SW, Wang J, Wang YP. 2015. Ameliorative effects of 5-hydroxymethyl-2-furfural (5-HMF) from Schisandra chinensis on alcoholic liver oxidative injury in mice. Int J Mol Sci 16: 2446 2457. https://doi.org/10.3390/ijms16022446

Lira AB, Montenegro CA, de Oliveira KM, de Oliveira Filho AA, da Paz AR, de Araújo MO, de Sousa DP, de Almeida CLF, da Silva TG, Lima CMBL, Diniz MFFM, Pessôa HLF. 2018. Isopropyl caffeate: A caffeic acid derivative-antioxidant potential and toxicity. Oxid Med Cell Longev 2018: 6179427.

https://doi.org/10.1155/2018/6179427

Mahdavi B, Yaacob WA, Din LB. 2017. Chemical composition, antioxidant, and antibacterial activity of essential oils from Etlingera sayapensis A.D. Poulsen \& Ibrahim. Asian Pac J Trop Med 10: 819 - 826.

https://doi.org/10.1016/j.apjtm.2017.08.006

Megaw J, Thompson TP, Lafferty RA, Gilmore BF. 2015. Galleria mellonella as a novel in vivo model for assessment of the toxicity of 1-alkyl-3-methylimidazolium chloride ionic liquids. Chemosphere 139: 197 201. https://doi.org/10.1016/j.chemosphere.2015.06.026

Mehreen A, Waheed M, Liaqat I, Arshad N. 2016. Phytochemical, antimicrobial, and toxicological evaluation of traditional herbs used to treat sore throat. Biomed Res Int 2016: 8503426. https://doi.org/10.1155/2016/8503426

Migliato KF, Baby AR, Zague V, Velasco MVR, Corrêa MA, Sacramento LVS, Salgado HRN. 2006. Ação farmacológica de Syzygium cumini (L.) Skeels. Acta Farm Bonaerense 25: 310 - 314.

Migliato KF, Moreira RRD, Mello JCP, Sacramento LVS, Corrêa MA, Salgado HRN. 2007. Controle da qualidade do fruto de Syzygium cumini (L.) Skeels. Rev Bras Farmacogn 17: 94 - 101.

https://dx.doi.org/10.1590/S0102-695X2007000100018

Millsop JW, Fazel N. 2016. Oral candidiasis. Clin Dermatol 34: 487-494.

https://doi.org/10.1016/j.clindermatol.2016.02.022

Mohamed AA, Ali SI, El-Baz FK. 2013. Antioxidant and antibacterial activities of crude extracts and essential oils of Syzygium cumini leaves. Plos One 8: e60269. https://doi.org/10.1371/journal.pone.0060269

Mopuri R, Ganjayi M, Meriga B, Koorbanally NA, Islam MS. 2018. The effects of Ficus carica on the activity of

Boletín Latinoamericano y del Caribe de Plantas Medicinales y Aromáticas / 553 
enzymes related to metabolic syndrome. J Food Drug Anal 26: 201 - 210.

https://doi.org/10.1016/j.jfda.2017.03.001

Morales G, Paredes A, Sierra P, Loyola LA. 2008. Antimicrobial activity of three Baccharis species used in the traditional medicine of northern Chile. Molecules 13: 790 - 794. https://doi.org/10.3390/molecules13040790

Muadcheingka T, Tantivitayakul P. 2015. Distribution of Candida albicans and non-albicans Candida species in oral candidiasis patients: Correlation between cell surface hydrophobicity and biofilm forming activities. Arch Oral Biol 60: 894 - 901. https://doi.org/10.1016/j.archoralbio.2015.03.002

Oliveira GF, Furtado NAJC, Silva Filho AA, Martins CHG, Bastos JK, Cunha WR, Andrade e Silva ML. 2007. Antimicrobial activity of Syzygium cumini (Myrtaceae) leaves extract. Braz J Microbiol 38: 381 - 384. https://doi.org/10.1590/S1517-83822007000200035

Paiva SG, Sabino AP, Carvalho MG, Ribeiro DD, Gomes KB, Santos MS, Oliveira MS, Lages GG, Dusse LMS, Fernandes AP. 2009. Polymorphisms in exons 6 and 7 of the ABO locus and their association with venous thrombosis in young Brazilian patients. Blood Coagul Fibrinolysis 20: 122 - 128. https://doi.org/10.1097/MBC.0b013e328323da99

Peleg AY, Hogan DA, Mylonakis E. 2010. Medically important bacterial-fungal interactions. Nat Rev Microbiol 8: 340 - 349. https://doi.org/10.1038/nrmicro2313

Peng TY, Don MM. 2013. Antifungal activity of in-vitro grown Earliella Scabrosa, a malaysian fungus on selected wood-degrading fungi of Rubberwood. J Phys Sci 24: 21 - 33.

Pereira JV, Freires IA, Castilho AR, da Cunha MG, Alves HS, Rosalen PL. 2016. Antifungal potential of Sideroxylon obtusifolium and Syzygium cumini and their mode of action against Candida albicans. Pharm Biol 54: 2312 - 2319. https://doi.org/10.3109/13880209.2016.1155629

Perlin DS, Rautemaa-Richardson R, Alastruey-Izquierdo A. 2017. The global problem of antifungal resistance: prevalence, mechanisms, and management. Lancet Infect Dis 17: e383 - e392. https://doi.org/10.1016/S1473-3099(17)30316-X

Rangel M, Malpezzi EL, Susini SM, de Freitas JC. 1997. Hemolytic activity in extracts of the diatom Nitzschia. Toxicon 35: 305 - 309. https://doi.org/10.1016/S0041-0101(96)00148-1

Rigobello ES, Scandelai APJ, Corso BL, Tavares CRG. 2015. Identificação de compostos orgânicos em lixiviado de aterro sanitário municipal por cromatografia gasosa acoplada a espectrometria de massas. Quím Nova 38: 794 - 800. https://doi.org/10.5935/0100-4042.20150092

Rochelle SLA, Sardi JCO, Freires IA, Galvão LCC, Lazarini JG, de Alencar SM, Rosalen PL. 2016. The antibiofilm potential of commonly discarded agro-industrial residues against opportunistic pathogens. Ind Crops Prod 87: 150 - 160. https://doi.org/10.1016/j.indcrop.2016.03.044

Rodrigues CF, Silva S, Henriques M. 2014. Candida glabrata: A review of its features and resistance. Eur J Clin Microbiol Infect Dis 33: 673 - 688. https://doi.org/10.1007/s10096-013-2009-3

Santos CC, Salvadori MS, Mota VG, Costa LM, de Almeida AAC, de Oliveira GAL, Costa JP, de Sousa DP, de Freitas RM, de Almeida RN. 2013. Antinociceptive and antioxidant activities of phytol in vivo and in vitro models. Neurosci J 2013: 949452. https://doi.org/10.1155/2013/949452

Sardi JCO, Polaquini CR, Freires IA, Galvāo LCC, Lazarini JG, Torrezan GS, Regasini LO, Rosalen PL. 2017. Antibacterial activity of diacetylcurcumin against Staphylococcus aureus results in decreased biofilm and cellular adhesion. J Med Microbiol 66: 816 - 824. https://doi.org/10.1099/jmm.0.000494

Satyal P, Powers CN, Parducci V R, McFeeters RL, Setzer WN. 2017. Chemical composition, enantiomeric distribution, and antifungal activity of the oleoresin essential oil of Protium amazonicum from Ecuador. Medicines (Basel) 4: 70. https://doi.org/10.3390/medicines4040070

Savastano C, de Oliveira Silva E, Gonçalves LL, Nery JM, Silva NC, Dias AL. 2016. Candida glabrata among Candida spp. From environmental health practitioners of a Brazilian hospital. Braz J Microbiol 47: 367 372. https://doi.org/10.1016/j.bjm.2015.05.001

Sharafutdinov IS, Trizna EY, Baidamshina DR, Ryzhikova MN, Sibgatullina RR, Khabibrakhmanova AM, Latypova LZ, Kurbangalieva AR, Rozhina EV, Klinger-Strobel M, Fakhrullin RF, Pletz MW, Bogachev MI, Kayumov AR, Makarewicz O. 2017. Antimicrobial effects of sulfonyl derivative of 2(5H)-furanone 
against planktonic and biofilm associated methicillin-resistant and -susceptible Staphylococcus aureus. Front Microbiol 8: 2246. https://doi.org/10.3389/fmicb.2017.02246

Sharif HB, Mukhtar MD, Mustapha Y, Lawal AO. 2015. Preliminary investigation of bioactive compounds and bioautographic studies of whole plant extract of Euphorbia pulcherrima on Escherichia coli, Staphylococcus aureus, Salmonella typhi and Pseudomonas aeruginosa. Adv Pharmaceut 2015: 485469. https://doi.org/10.1155/2015/485469

Sharma S, Saxena DC, Riar CS. 2018. Changes in the GABA and polyphenols contents of foxtail millet on germination and their relationship with in vitro antioxidant activity. Food Chem 245: 863 - 870. https://doi.org/10.1016/j.foodchem.2017.11.093

Siddiqui ZN, Farooq F, Musthafa TNM, Ahmad A, Khan AU. 2013. Synthesis, characterization and antimicrobial evaluation of novel halopyrazole derivatives. J Saudi Chem Soc 17: 237 - 243.

https://doi.org/10.1016/j.jscs.2011.03.016

Silva-Rocha WP, de Brito Lemos VL, Ferreira MRA, Soares LAL, Svidzisnki TIE, Milan EP, Chaves GM.2015. Effect of the crude extract of Eugenia uniflora in morphogenesis and secretion of hydrolytic enzymes in Candida albicans from the oral cavity of kidney transplant recipients. BMC Complement Altern Med 15: 6. https://doi.org/10.1186/s12906-015-0522-x

Srivastava S, Chandra D. 2013. Pharmacological potentials of Syzygium cumini: A review. J Sci Food Agric 93: 2084 - 2093. https://doi.org/10.1002/jsfa.6111

Sunita A, Manju S. 2017. Phytochemical examination and GC-MS analysis of methanol and ethyl-acetate extract of root and stem of Gisekia Pharnaceoides Linn. Res J Pharmaceut Biol Chem Sci 8: 168 - 174.

Teoh YP, Don MM, Ujang S. 2011. Media selection for mycelia growth, antifungal activity against wooddegrading fungi, and GC-MS study by Pycnoporus sanguineus. BioResources 6: 2719 - 2731. https://doi.org/10.15376/biores.6.3.2719-2731

Teoh YP, Don MM. 2014. Mycelia growth and production of total flavonoids and 4H-pyran-4-one, 2,3-dihydro3,5-dihydroxy-6-methyl-by Schizophyllum commune using a bubble column bioreactor considering aeration effect and mass transfer study. Chem Biochem Eng Quart 28: 553 - 559.

https://doi.org/10.15255/CABEQ.2014.2024

Trizna EY, Khakimullina EN, Latypova LZ, Kurbangalieva AR, Sharafutdinov IS, Evtyugin VG, Babynin EV, Bogachev MI, Kayumov AR. 2015. Thio derivatives of 2(5H)-furanone as inhibitors against Bacillus subtilis biofilms. Acta Naturae 7: 102 - 107. https://doi.org/10.32607/20758251-2015-7-2-102-107

Tupe RS, Kulkarni A, Adeshara K, Shaikh S, Shah N, Jadhav A. 2015. Syzygium jambolanum and Cephalandra indica homeopathic preparations inhibit albumin glycation and protect erythrocytes: An in vitro study. Homeopathy 104: 197 - 204. https://doi.org/10.1016/j.homp.2015.02.009

Vo NNQ, Fukushima EO, Muranaka T. 2017. Structure and hemolytic activity relationships of triterpenoid saponins and sapogenins. J Nat Med 71: 50 - 58. https://doi.org/10.1007/s11418-016-1026-9

Waczuk EP, Kamdem JP, Abolaji AO, Meinerz DF, Caeran Bueno D, Do Nascimento Gonzaga TKS, Do Canto Dorow TS, Boligon AA, Athayde ML, Da Rocha JBT, Ávila DS. 2015. Euphorbia tirucalli aqueous extract induces cytotoxicity, genotoxicity and changes in antioxidant gene expression in human leukocytes. Toxicol Res 4: 739 - 748. https://doi.org/10.1039/c4tx00122b

Żbikowska B, Franiczek R, Sowa A, Połukord G, Krzyżanowska B, Sroka Z. 2017. Antimicrobial and antiradical activity of extracts obtained from leaves of five species of the genus Bergenia: Identification of antimicrobial compounds. Microb Drug Resist 23:771-780. https://doi.org/10.1089/mdr.2016.0251

Zhao L, Chen J, Su J, Li L, Hu S, Li B, Zhang X, Xu Z, Chen T. 2013. In vitro antioxidant and antiproliferative activities of 5-hydroxymethylfurfural. J Agric Food Chem 61: 10604 - 10611.

https://doi.org/10.1021/jf403098y

Boletín Latinoamericano y del Caribe de Plantas Medicinales y Aromáticas / 555 
Complementary material

Effect of Syzygium cumini leaves extract and Nystatin on the growth kinetics of Candida albicans (ATCC 10231). The results are expressed as mean $\mathrm{CFU} / \mathrm{mL}$ )

Different letters indicate statistically significant diferences

\begin{tabular}{|c|c|c|c|c|c|c|}
\hline $\mathbf{T}$ & $\mathbf{G r}$ & Conc. & Mean & SD & * & $p$ \\
\hline Oh & $\begin{array}{l}\text { Nys } \\
\text { VC } \\
\text { CC }\end{array}$ & $\begin{array}{l}\text { MIC } \\
\text { 2xMIC } \\
4 x M I C \\
\text { MIC } \\
2 x M I C \\
4 x M I C\end{array}$ & $\begin{array}{c}1566,67 \\
2133,33 \\
1933,33 \\
1733,33 \\
2500,0 \\
2433,33 \\
611,11 \\
655,0\end{array}$ & $\begin{array}{c}152,75 \\
896,29 \\
577,35 \\
776,75 \\
1135,78 \\
115,47 \\
280,38 \\
72,78\end{array}$ & $\begin{array}{l}\mathrm{a} \\
\mathrm{a} \\
\mathrm{a} \\
\mathrm{a} \\
\mathrm{a} \\
\mathrm{a} \\
\mathrm{a} \\
\mathrm{a}\end{array}$ & 0,697 \\
\hline 1h & $\begin{array}{l}\mathrm{SC} \\
\mathrm{Nys}\end{array}$ & $\begin{array}{l}\text { MIC } \\
2 x M I C \\
4 x M I C \\
\text { MIC } \\
2 x M I C \\
4 x M I C\end{array}$ & $\begin{array}{c}1800,0 \\
1066,67 \\
1200,0 \\
1433,33 \\
900,0 \\
733,33 \\
233,33 \\
444,33\end{array}$ & $\begin{array}{c}458,26 \\
115,47 \\
871,78 \\
650,64 \\
624,5 \\
305,51 \\
150,0 \\
120,3\end{array}$ & $\begin{array}{l}\mathrm{a} \\
\mathrm{a} \\
\mathrm{a} \\
\mathrm{a} \\
\mathrm{a} \\
\mathrm{a} \\
\mathrm{a} \\
\mathrm{a}\end{array}$ & 0,059 \\
\hline $2 \mathrm{~h}$ & $\begin{array}{l}\text { Nys } \\
\text { vC } \\
\text { CC }\end{array}$ & $\begin{array}{l}\text { MIC } \\
2 \text { XMIC } \\
4 x M I C \\
\text { MIC } \\
2 x M I C \\
4 x M I C\end{array}$ & $\begin{array}{c}700,0 \\
1033,33 \\
1100,0 \\
533,33 \\
500,0 \\
133,33 \\
300,0 \\
100,0\end{array}$ & $\begin{array}{c}458,26 \\
665,83 \\
458,26 \\
321,46 \\
264,58 \\
152,75 \\
223,61 \\
86,6\end{array}$ & $\begin{array}{l}\mathrm{a} \\
\mathrm{a} \\
\mathrm{a} \\
\mathrm{a} \\
\mathrm{a} \\
\mathrm{a} \\
\mathrm{a} \\
\mathrm{a}\end{array}$ & 0,100 \\
\hline $3 h$ & $\begin{array}{l}\text { Nys } \\
\text { vC } \\
\text { CC }\end{array}$ & $\begin{array}{l}\text { MIC } \\
\text { 2xMIC } \\
4 x M I C \\
\text { MIC } \\
\text { 2xMIC } \\
4 x M I C\end{array}$ & $\begin{array}{c}1033,33 \\
1033,33 \\
666,67 \\
633,33 \\
800,0 \\
433,33 \\
133,33 \\
355,33\end{array}$ & $\begin{array}{c}901,85 \\
1040,83 \\
152,75 \\
208,17 \\
624,5 \\
450,92 \\
141,42 \\
344,56\end{array}$ & $\begin{array}{l}\mathrm{a} \\
\mathrm{a} \\
\mathrm{a} \\
\mathrm{a} \\
\mathrm{a} \\
\mathrm{a} \\
\mathrm{a} \\
\mathrm{a}\end{array}$ & 0,095 \\
\hline $4 \mathrm{~h}$ & Nys & $\begin{array}{l}\text { MIC } \\
\text { 2xMIC } \\
4 \text { xMIC } \\
\text { MIC } \\
2 x M I C \\
4 x M I C\end{array}$ & $\begin{array}{c}333,33 \\
766,67 \\
966,67 \\
700,0 \\
266,67 \\
266,67 \\
100,0 \\
166,33\end{array}$ & $\begin{array}{c}57,74 \\
57,74 \\
351,19 \\
721,11 \\
115,47 \\
152,75 \\
158,11 \\
152,53 \\
\end{array}$ & $\begin{array}{l}\mathrm{a} \\
\mathrm{a} \\
\mathrm{a} \\
\mathrm{a} \\
\mathrm{a} \\
\mathrm{a} \\
\mathrm{a} \\
\mathrm{a}\end{array}$ & 0,135 \\
\hline $6 h$ & Nys & $\begin{array}{l}\text { MIC } \\
2 x M I C \\
4 x M I C \\
\text { MIC } \\
2 x M I C \\
4 x M I C\end{array}$ & $\begin{array}{c}1666,67 \\
1000,0 \\
1600,0 \\
566,67 \\
266,67 \\
100,0 \\
344,44 \\
655,0\end{array}$ & $\begin{array}{c}1858,31 \\
360,56 \\
1228,82 \\
814,45 \\
288,68 \\
173,21 \\
412,65 \\
692,96\end{array}$ & $\begin{array}{l}\mathrm{a} \\
\mathrm{a} \\
\mathrm{a} \\
\mathrm{a} \\
\mathrm{a} \\
\mathrm{a} \\
\mathrm{a} \\
\mathrm{a}\end{array}$ & 0,096 \\
\hline $8 h$ & SC & $\begin{array}{l}\text { MIC } \\
2 x M I C\end{array}$ & $\begin{array}{l}5300,0 \\
3000,0\end{array}$ & $\begin{array}{l}4256,76 \\
2457,64\end{array}$ & $\begin{array}{l}\mathrm{a} \\
\mathrm{a}\end{array}$ & 0,001 \\
\hline
\end{tabular}

Boletín Latinoamericano y del Caribe de Plantas Medicinales y Aromáticas / 556 


\begin{tabular}{|c|c|c|c|c|c|c|}
\hline & $\begin{array}{l}\text { Nys } \\
\text { VC } \\
\text { CC }\end{array}$ & $\begin{array}{l}\text { 4xMIC } \\
\mathrm{MIC} \\
2 \mathrm{xMIC} \\
4 \mathrm{xMIC}\end{array}$ & $\begin{array}{c}3100,0 \\
666,67 \\
66,67 \\
0,0 \\
3022,22 \\
5400,0\end{array}$ & $\begin{array}{c}1539,48 \\
305,51 \\
57,74 \\
0,0 \\
3592,28 \\
4267,32\end{array}$ & $\begin{array}{c}\mathrm{a} \\
\mathrm{b} \\
\mathrm{bc} \\
\mathrm{c} \\
\mathrm{a} \\
\mathrm{a}\end{array}$ & \\
\hline $12 \mathrm{~h}$ & $\begin{array}{l}\text { SC } \\
\text { Nys } \\
\\
\text { VC } \\
\text { CC }\end{array}$ & $\begin{array}{l}\mathrm{MIC} \\
2 \mathrm{xMIC} \\
4 \mathrm{xMIC} \\
\mathrm{MIC} \\
2 \mathrm{xMIC} \\
4 \mathrm{xMIC}\end{array}$ & $\begin{array}{c}10000,0 \\
10000,0 \\
10000,0 \\
466,67 \\
466,67 \\
166,67 \\
7877,78 \\
10000,0\end{array}$ & $\begin{array}{c}0,0 \\
0,0 \\
0,0 \\
115,47 \\
461,88 \\
288,68 \\
3281,68 \\
0,0\end{array}$ & $\begin{array}{l}\mathrm{b} \\
\mathrm{b} \\
\mathrm{c} \\
\mathrm{a} \\
\mathrm{a} \\
\mathrm{a} \\
\mathrm{a} \\
\mathrm{a}\end{array}$ & 0,001 \\
\hline $24 h$ & $\begin{array}{l}\text { SC } \\
\text { Nys } \\
\\
\text { VC } \\
\text { CC }\end{array}$ & $\begin{array}{l}\mathrm{MIC} \\
2 \mathrm{xMIC} \\
4 \mathrm{xMIC} \\
\mathrm{MIC} \\
2 \mathrm{xMIC} \\
4 \mathrm{xMIC}\end{array}$ & $\begin{array}{c}10000,0 \\
10000,0 \\
10000,0 \\
6800,0 \\
466,67 \\
0,0 \\
10000,0 \\
10000,0\end{array}$ & $\begin{array}{c}0,0 \\
0,0 \\
0,0 \\
5542,56 \\
723,42 \\
0,0 \\
0,0 \\
0,0\end{array}$ & $\begin{array}{l}\mathrm{b} \\
\mathrm{b} \\
\mathrm{b} \\
\mathrm{a} \\
\mathrm{a} \\
\mathrm{a} \\
\mathrm{a} \\
\mathrm{a}\end{array}$ & 0,001 \\
\hline
\end{tabular}

(Legend: T= Time; Gr =Groups (Sc: $S$. cumini extract; Nyst: nystatin; VC: vehicle control; GC: growth control); Mean: mean CFU/mL; SD: standard deviation; $p$ : $p$-value of the statistical analysis 